RHODORA, Vol. 118, No. 973, pp. 46-85, 2016

(C) Copyright 2016 by the New England Botanical Club

doi: 10.3119/15-11; first published on-line April 20, 2016.

\title{
A COMPARATIVE STUDY OF THE FLORA AND SOILS OF GREAT DUCK AND LITTLE DUCK ISLANDS, MAINE, USA
}

\author{
LuKa Negoita
}

Syracuse University, Life Sciences Complex, 107 College Place, Syracuse, NY 13244

e-mail: lnegoita@syr.edu

Matthew Dickinson

P.O. Box 571, Cape Neddick, ME 03902

Glen H. Mittelhauser

Maine Natural History Observatory, 317 Guzzle Road, Gouldsboro, ME 04607

\section{Nishanta RajaKarunA}

College of the Atlantic, 105 Eden Street, Bar Harbor, ME 04609; Unit for Environmental Sciences and Management, North-West University, Private Bag X6001, Potchefstroom, 2520, South Africa

\begin{abstract}
Strong environmental gradients and varied land-use practices have generated a mosaic of habitats harboring distinct plant communities on islands on the coast of Maine. Botanical studies of Maine's islands, however, are generally limited in number and scope. Baseline studies of Maine's islands are necessary for assessing vegetation dynamics and changes in habitat conditions in relation to environmental impacts imposed by climate change, rising sea levels, invasive species, pests and pathogens, introduced herbivores, and human disturbance. We conducted a survey of the vascular plants and soils of forest, field, and ocean-side communities of Great Duck and Little Duck Islands, ME. These islands differ in environmental and land-use features, and in particular the presence of mammalian herbivores; Great Duck Island has had over a century of continuous mammalian herbivory while Little Duck Island has been largely free of mammalian herbivores over the last 100 years. We recorded 235 vascular plant species in 61 families on the Duck Islands, 106 of which were common to both islands. The composition, abundances, and diversity of plant species substantially differed within similar plant communities between the islands. These differences were particularly evident in the forest communities where Little Duck Island had significantly greater sapling regeneration and a more recent peak in tree recruitment. Soil properties also significantly differed between these islands, with a higher $\mathrm{pH}$ in all three communities and higher $\mathrm{P}, \mathrm{Ca}$, and $\mathrm{K}$ in field, forest, and ocean-side communities, respectively, on Little Duck Island, and higher soluble salts in forest and ocean-side communities of Great Duck Island. Together, our findings suggest that soil characteristics and the dominance and regeneration of
\end{abstract}


vascular plant species can differ substantially even between adjacent islands with otherwise similar geologic characteristics and glacial history, and that mammalian herbivory along with other ecological factors may be important drivers of these differences.

Key Words: coastal ecology, insular ecology, baseline survey, mammalian herbivory, Gulf of Maine, vascular plants, edaphic features

The coastline of northeastern North America includes a mosaic of islands with varied topography, climate, bedrock and surface geology, and with complex postglacial and post-settlement histories (McMaster 2005; Turcotte and Butler 2006). The strong environmental gradients, along with historical factors, have produced varied habitats harboring a wide range of species and vegetation types on islands of the region (Clayden et al. 2010; Greene et al. 2005). The state of Maine, located at the intersection of temperate and boreal bioclimatic zones in northeastern North America, is home to 2103 vascular plant taxa (Campbell et al. 1995) and 104 natural plant communities (Gawler and Cutko 2010). Although more than 3000 islands hug the coastline of Maine, botanical studies of the state's islands are limited in number and scope, with the vast majority focusing on floristics (Folger and Wayne 1986; Greene et al. 2005; Lesser 1977; Lewis 1983; Mulligan 1980; Pike and Hodgdon 1962; Rand 1900; Rappaport and Wesley 1985; Redfield 1885, 1893; Stebbins 1929; Wise 1970), and a few on plant-habitat relations (Ellis et al. 2006, 2011; Hodgdon and Pike 1969; Nichols and Nichols 2008; Rajakaruna et al. 2009; Wherry 1926). Long-term and systematic floristic studies on Maine's islands are necessary for assessing long-term vegetation dynamics, including changes in habitat conditions, especially in light of significant environmental impacts imposed by climate change, rising sea levels, invasive species, pests and pathogens, introduced herbivores, and human disturbances on island ecosystems (Caujapé-Castells et al. 2010; Harris et al. 2012).

The Great Duck and Little Duck Islands, ME, provide an important setting for establishing a baseline ecological study to assess long-term changes to plant diversity, community composition, and habitat conditions. The environmental factors that differ between these islands may offer some insights into the current and future ecologies of these islands. For example, Great Duck Island has had over a century of continuous mammalian herbivory in the form of sheep and hares, whereas Little Duck Island has been largely free of mammalian herbivores. Introduced mammalian herbivores are a major conservation concern, especially in predator-free habitat fragments such as islands where herbivores can severely limit tree recruitment (Peterson et 


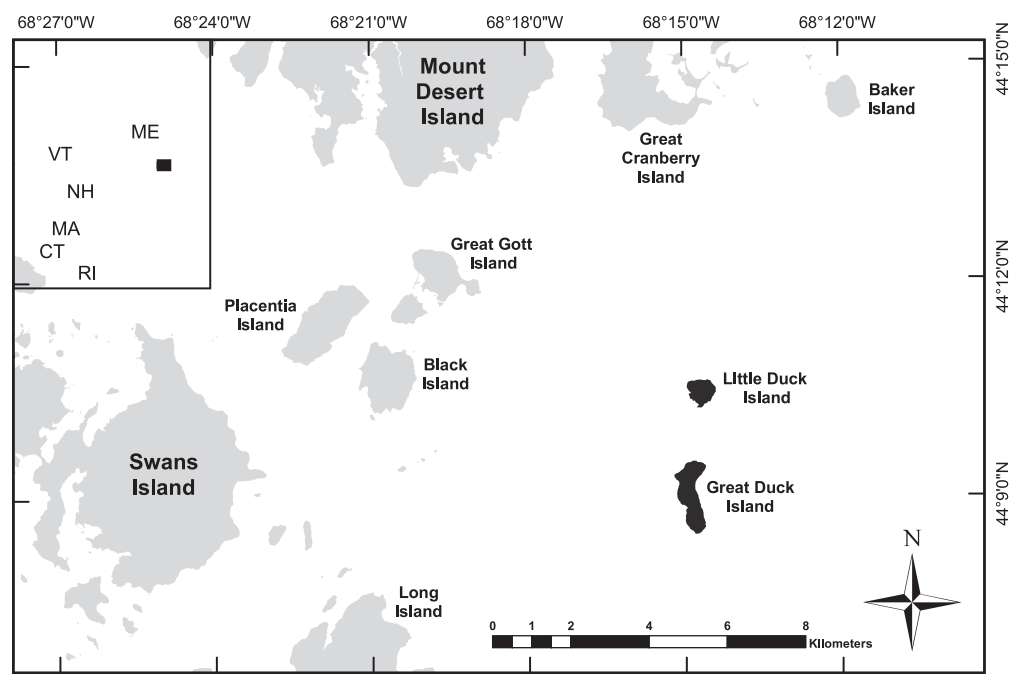

Figure 1. Study area, showing location of Great Duck and Little Duck Islands, Maine, USA.

al. 2005; Terborgh et al. 2001). These islands also differ in topography and other aspects of land-use history, which may in turn drive plant communities and edaphic features. In this study, we conducted a survey to describe the vascular flora and associated soils of the islands' natural plant communities. We compared species composition and diversity, tree demography, and sapling regeneration to assess the potential impact of long-term herbivory and other environmental and human factors on plant communities of the two islands.

\section{MATERIALS AND METHODS}

Site description. The Duck Islands, $\operatorname{ME}\left(44.16^{\circ} \mathrm{N}, 68.25^{\circ} \mathrm{W}\right)$ are composed of Little Duck Island (LDI, 35 ha) and Great Duck Island (GDI, 91 ha), located about eight kilometers south of Mount Desert Island in the Gulf of Maine (Figure 1). The climate of the region is typically characterized by cool summers and mild winters (McMahon 1990). Average high and low annual temperatures for the nearby town of Mount Desert are 11.9 and $0.1^{\circ} \mathrm{C}$, respectively, with an average annual precipitation of $114.7 \mathrm{~cm}$ (between 1981 and 2010; US Climate Data 2015).

The Duck Islands have similar bedrock geology and glacial history (Osberg et al. 1985), with parent material typically composed of coarse 
acidic glacial till (Jordan 1988). Parent material varies in depth, with occasional exposed bedrock, especially near the ocean. The islands were connected to the mainland for about $500 \mathrm{y}$ following glacial retreat around 11,000 YBP; sea-level has increased since, reaching close to current levels around 4000 YBP (Barnhardt et al. 1995). The islands are partially covered by forests dominated by Picea spp. and Abies balsamea and old-fields dominated by a variety of forbs, shrubs, and graminoids. Each island also harbors a saline wetland with a different assemblage of species. Redfield (1885, 1893), Rand (1900), Lesser (1977), Rappaport and Wesley (1985), and Folger and Wayne (1986) offered preliminary accounts of vascular plants of the Duck Islands.

These islands differ substantially in their history of recent human use, particularly regarding mammalian herbivory. Although both islands have been under conservation protection since the 1970s, LDI has been protected as a bird sanctuary since 1908 (McLane 1989). The last record of sheep grazing on LDI- a common practice on Maine islands (Conkling 2011) - was in the late 19th century, and no permanent populations of grazing mammals have been reported on LDI in the past 100 y (McLane 1989). Great Duck Island, however, had a history of permanent human habitation and sheep grazing until 1986, when the lighthouse at the south end of the island became automated and lighthouse keepers were no longer needed. In addition, both European hare (Lepus europaeus) and snowshoe hare ( $L$. americanus) were introduced to GDI in the late 1940s for recreational hunting. The hare populations have since expanded and were estimated at 500 individuals or, about 6 hares per ha in 1985 (Folger and Wayne 1986). We made numerous sightings during our fieldwork in 2011, indicating the hares on GDI were still abundant. This is in contrast to LDI, where we observed no signs of any mammalian herbivores in 2010. Both GDI and LDI also harbor large populations of nesting seabirds, including black guillemot (Cepphus grille), common eider (Somateria mollissima), double-crested cormorant (Phalacrocorax auritus), great cormorant ( $P$. carbo), great black-backed gull (Larus marinus), and herring gull (L. argentatus), as well as the threatened Leach's storm-petrel (Oceanodroma leucorhoa; Allen et al. 2012).

Vegetation survey. We established and surveyed sixty $20 \mathrm{~m}^{2}$ plots on LDI during June-August of 2010 and on GDI during June-August of 2011. Plots $(10 \times 2 \mathrm{~m})$ were randomly located within three strata: communities dominated by a woody canopy (forest), mostly herbaceous vegetation without a woody canopy (field), and the vegetation found within proximity of the ocean (excluding the rocky berm; oceanside). These were the most conspicuous natural communities found on 
both islands. Prior to fieldwork, we delineated these vegetation communities from aerial photographs (North American Proficiency Testing Program 2009) and later refined the maps based on field observations. The forest community was defined by the presence of a woody canopy at least $2 \mathrm{~m}$ in height and at least $10 \mathrm{~m}$ from the rocky shoreline. The field community was defined by the presence of herbs, the absence of a woody canopy greater than $2 \mathrm{~m}$ in height, and by a distance of at least $10 \mathrm{~m}$ from the rocky shoreline. The ocean-side community was defined as the vegetation within $10 \mathrm{~m}$ of the rocky shoreline. To randomly select plot locations in the forest and field vegetation communities, we first generated a geo-referenced map of the island and overlaid a series of plots based on a 0.40 ha grid. Plots were excluded from consideration if they occurred within community transition zones on our delineated maps. Using a GPS unit (Garmin eTrex Venture HC, Olathe, KS), we navigated to each randomly selected plot within each stratum. Based on our field interpretations, plots that occurred at the edges of community transition zones were moved away from the transition edges. These plots were moved $30 \mathrm{~m}$ in the cardinal direction (north, east, south, or west) that put them farthest into the community they represented. The long sides of all plots were oriented north-south. Ocean-side plots were systematically placed around the perimeter of each island. These ocean-side plots were oriented perpendicular to the shoreline, beginning at the first occurrence of $100 \%$ vegetation cover from the rocky shore. In total, we established 60 plots on LDI ( 29 forest, 20 field, 11 ocean-side), and 60 plots on GDI (29 forest, 19 field, 12 ocean-side).

We subdivided each $10 \times 2 \mathrm{~m}$ plot into five $2 \times 2 \mathrm{~m}$ subplots to allow for easier estimation of percent cover of each vascular plant species below a height of $2 \mathrm{~m}$. Percent cover was estimated for each species within each subplot to the nearest one percent. Species represented by less than one percent were recorded as $0.5 \%$, and species represented by one or only a few seedlings were recorded as $0.1 \%$. Percent cover data from the five subplots were averaged to represent each plot. All individuals $>5 \mathrm{~cm}$ diameter at breast height (DBH) in each plot were counted and cored at breast height, and the age of each tree was estimated in the field by counting rings with a loupe and adding 10 to conservatively account for age at breast height. Saplings $(<5 \mathrm{~cm} \mathrm{DBH}$, and $>$ than $20 \mathrm{~cm}$ height $)$ of each tree species were counted within each plot.

Although the plot surveys provided a measure of species abundances on the islands, this method is likely to miss rare plants. Our plot surveys also did not include transitional habitats such as between forest and field, saline wetlands, or the rocky berm where some species were 
exclusively found. Thus, in addition to our plot surveys we traversed the islands, spending time in other habitats in order to generate complete species lists for each island. Plants within and outside of plots were identified in the field to the species level, if possible, or collected and identified in the lab with a dissecting microscope and taxonomic key (Haines 2011). Several taxa were identified only to the genus level due to missing reproductive structures necessary for identification. Infraspecific taxa were not considered in our study. All vascular nomenclature follows Haines (2011). A complete list of vascular taxa for each island is presented in the Appendix. Voucher specimens have been deposited at the herbarium of College of the Atlantic, Bar Harbor, ME (HCOA). We compared the list of vascular plant species tallied on the Duck Islands to those of historic surveys of these islands (Folger and Wayne 1986; Lesser 1977; Rappaport and Wesley 1985; Redfield 1885, 1893) as a preliminary assessment of historic change in the species composition of these islands.

Soil analyses. Soil samples were collected from the top $10 \mathrm{~cm}$ of mineral soil, in two opposing corners of each $10 \times 2 \mathrm{~m}$ plot, and these were combined to form a single $200 \mathrm{~g}$ sample for each plot. Samples were air dried in the laboratory and then sent to A\&L Western Laboratories Inc. (Modesto, CA) where they were tested for nitrogen $\left(\mathrm{N}, \mathrm{NO}_{3^{-}}\right)$, phosphorus ( $\mathrm{P}$, Weak-Bray), potassium $(\mathrm{K})$, calcium $(\mathrm{Ca})$, magnesium $(\mathrm{Mg})$, sodium $(\mathrm{Na})$, sulfur $\left(\mathrm{S}, \mathrm{SO}_{4^{-}}\right), \mathrm{pH}$, percent organic matter (OM), estimated nitrogen release (ENR), soluble salts (SS), and cation exchange capacity (CEC). All soil testing procedures followed the Soil and Plant Analytical Methods of the North American Proficiency Testing Program (NAPT 2011).

Statistical analyses. Data were analyzed to describe and compare species diversity, edaphic features, and woody regeneration between islands within similar vegetation communities. All statistical analyses were conducted using the $\mathrm{R}$ language and environment for statistical computing ( $\mathrm{R}$ Core Team 2014).

We compared soil features between the two islands using two methods. First, we conducted a principal components analysis (PCA) as a way to visually inspect soil differences in multivariate space and to extract the soil features most important for describing this variation. The PCA was calculated using soil data that were log-transformed to aid with assumptions of normality. For each community, the two primary axes - those that explained the most multivariate variation-were plotted and were labeled with the soil features important for driving this variation (features with loadings greater than 0.3 were included). Second, we tested for differences in soil features within communities and 
between islands, using two-tailed Mann-Whitney tests for each comparison. The Mann-Whitney test is a non-parametric analog to the t-test, appropriate for comparisons of non-normally distributed data such as our soil data. We adjusted p-values using the Hochberg method to reduce the chance of Type I errors in repeated testing, generating more conservative comparisons (Hochberg 1988).

Finally, we compared the diversity, composition, abundance, and regeneration of the common species on each island. Understory species composition (species with vegetation cover within $2 \mathrm{~m}$ from the ground) was assessed using plot mean percent cover data in each vegetation type. Forest overstory composition was assessed using stem counts of each species (individuals $>5 \mathrm{~cm} \mathrm{DBH}$ ). We also compared woody regeneration between islands by qualitatively comparing tree demography. Estimates of tree ages were binned by decade, and plotted as a density histogram where all bins for an island sum to one. We tested for differences in sapling numbers $(<5 \mathrm{~cm} \mathrm{DBH}$, and $>$ than 20 $\mathrm{cm}$ height) in forests between islands and accounted for differences in soil features by using negative binomial models of the form:

Model 1. Sapling count $_{\text {plot }} \sim$ soil PCA1 $1_{\text {plot }}+$ soil PCA2 $2_{\text {plot }}$

Model 2. Sapling count plot $\sim$ soil PCA1 plot + soil PCA2 $2_{\text {plot }}+$ island

in which the primary axes of soil variation from our PCA were used to generate a null model of sapling count as a function of soil features (Model 1). Our second model included island as an explanatory variable for sapling counts (Model 2). We then used a likelihood-ratio test to assess the importance of including island as an explanatory variable for sapling count. This approach allowed us to test for differences in regeneration between islands while accounting for soil differences. Finally, diversity indices were calculated for each community on each island. Alpha diversity was calculated as the species richness within each plot. The Shannon-Wiener diversity index, calculated using base $e$, additionally accounted for species evenness as determined by percent cover of each species in plots. Evenness tests the extent to which species abundance distributions are skewed towards few dominant species versus many evenly abundant species. A plot represented by species with equal relative cover is equivalent to the natural $\log$ of alpha diversity.

RESULTS

In total, we identified 235 plant taxa in 61 families on the Duck Islands-189 in 56 families on GDI and 151 in 47 families on LDI 
(Appendix). There were 83 species unique to GDI and 46 unique to LDI, with 106 common between both islands (45\%). In the 60 vegetation plots on each island, we found 130 species in 42 families on GDI and 84 species in 38 families on LDI. Thirty-one species were nonnative, $27 \%$ of species on LDI and $24 \%$ on GDI. Furthermore, 31 species were newly recorded for GDI, and 44 were newly recorded on LDI. A total of 62 species were previously recorded on GDI (from multiple surveys dating between 1885 to 1986), but not found in the current study. A total of 30 species were previously recorded on LDI, but not found in the current study.

Forest. The forest community of GDI was dominated by an overstory of Picea spp. with Betula papyrifera, Sorbus spp., and Abies balsamea found in only one or two forest plots (Figure 2). The overstory on LDI was dominated by both A. balsamea and Picea spp., and included a greater richness and abundance of broad-leaved deciduous species such as Acer pensylvanicum, A. spicatum, and $B$. papyrifera (Figure 2). We also found a significantly greater number of regenerating tree saplings per plot on LDI $(17.97 \pm 4.37 \mathrm{SEM})$ than on GDI (2.41 \pm 1.78 SEM), even after allowing for differences in soils ( $p$ $\left.<0.001 ; \chi^{2}(1)=12.17\right)$. This included greater richness of both coniferous and deciduous sapling species on LDI (Figure 3), including Abies balsamea and Acer spicatum, with occasional Sorbus spp. and Acer pensylvanicum. The saplings on GDI mainly consisted of $B$. papyrifera and $S$. americana, though these saplings were only encountered in one or very few forest plots (Figure 3). The understory of each island was dominated by Dryopteris spp. (Figure 4). Other than wood fern, the understory of GDI was mainly composed of Chamaepericlymenum canadense, Maianthemum canadense, and Oclemena acuminata, whereas $A$. balsamea and $A$. spicata dominated the understory cover on LDI. Clintonia borealis and Streptopus lanceolatus were also frequently encountered in the forest understory community of LDI (Figure 4). A mean alpha diversity of $11.85( \pm 0.84)$ species was encountered in forest plots on GDI, and a mean alpha diversity of 14.14 ( \pm 0.64$)$ species was encountered in forest plots on LDI (Table 2). See Table 2 for the Shannon-Wiener diversity index. Tree recruitment peaked in the 1940s for GDI, when close to $25 \%$ of the trees surveyed had reestablished (Figure 5). Tree recruitment on LDI, in contrast, peaked in the $1960 \mathrm{~s}$, when over $25 \%$ of trees surveyed had reestablished (Figure 5).

Field. The field community on both islands consisted of a mix of forbs, graminoids, and shrubs. The field community on GDI was 


\section{Forest Overstory}

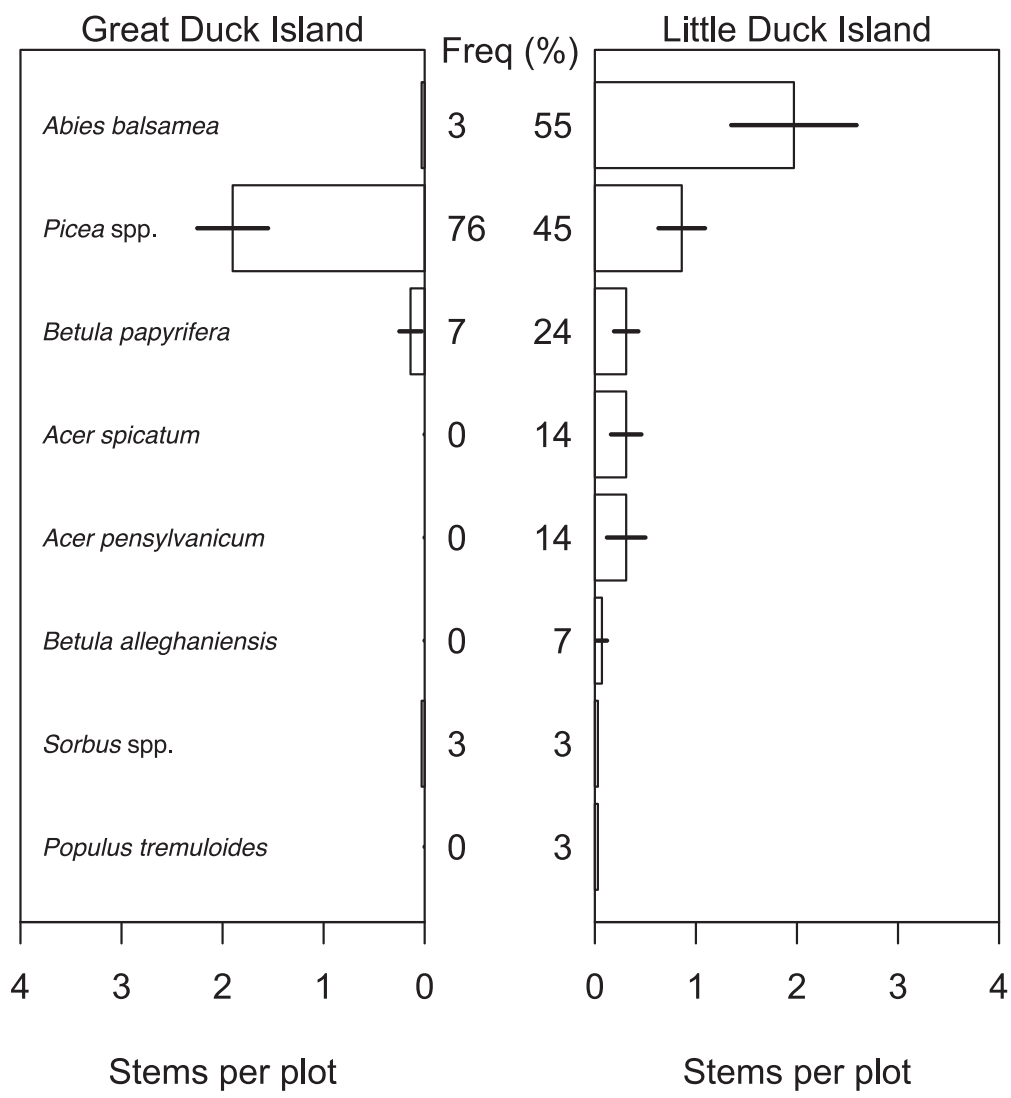

Figure 2. Tree composition of the forest community on Great Duck and Little Duck Islands during the summers of 2010-2011. Relative species abundance is determined as mean stem count (individuals $>5 \mathrm{~cm} \mathrm{DBH}$; \pm standard error). Frequency refers to the percent of plots on each island occupied by stems.

characterized by a dominant layer of Festuca rubra, with occasional Vaccinium angustifolium, Deschampsia flexuosa, and Rubus hispidus, and with the less dominant, but frequent occurrence of $R$. idaeus, Achillea millefolium, Rumex acetosella, and Fragaria virginiana (Figure 6). The field on LDI was dominated by Poa pratensis. Other abundant or frequent species on LDI included Rubus idaeus, Elymus repens, F. virginiana, Moehringia lateriflora, Chamerion angustifolium, and Soli- 


\section{Forest Saplings}

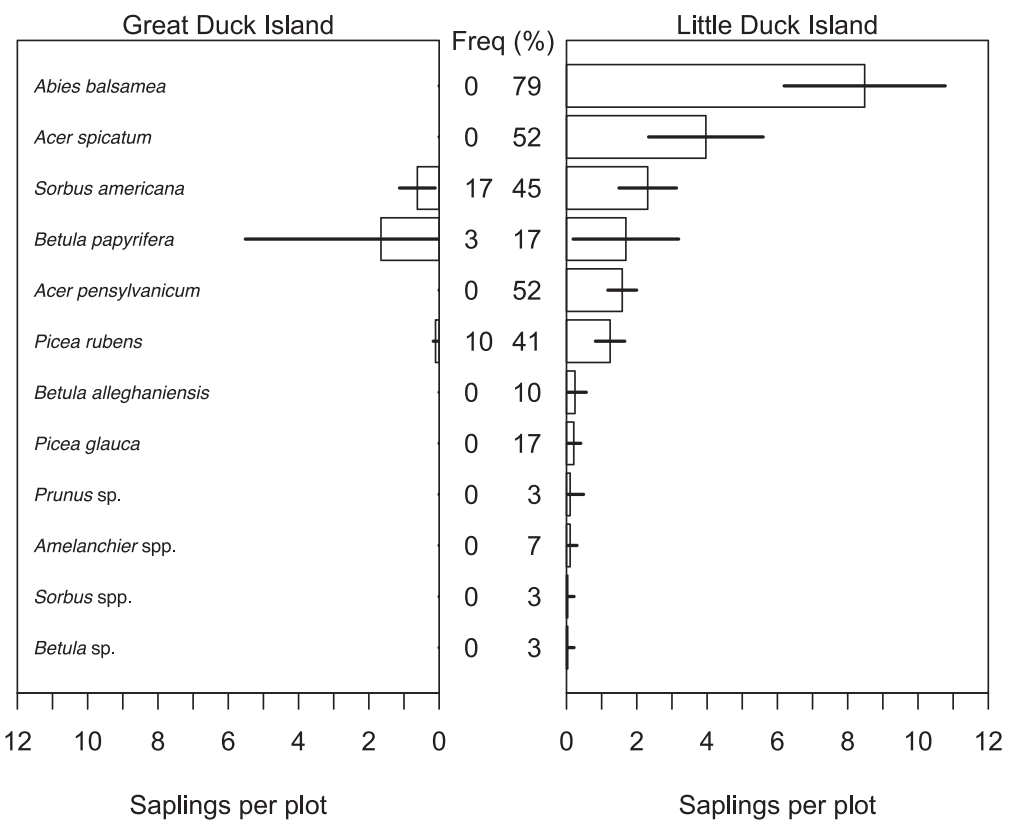

Figure 3. Saplings found in each vegetative community on Great Duck and Little Duck Islands, during the summers of 2010-2011. Saplings are defined as trees $>20 \mathrm{~cm}$ in height but $<5 \mathrm{~cm} \mathrm{DBH}$. Frequency refers to the percent of plots on each island occupied by stems. Overall, sapling counts within each plot differed significantly between islands in the forest community even when accounting for edaphic differences; $\mathrm{p}<0.001 ; \chi^{2}(1)=12.17$.

dago rugosa (Figure 6). A mean alpha diversity of $19( \pm 1.57)$ species was encountered in field plots on GDI, and a mean alpha diversity of $12.65( \pm 0.81)$ species was encountered in field plots on LDI (Table 2). See Table 2 for the Shannon-Wiener diversity index.

Ocean-side. The GDI ocean-side community was characterized by its dominant field species, Festuca rubra and Symphyotrichum novibelgii, and a generally sparse cover of Agrostis spp. and Calystegia sepium (Figure 7). In contrast to the ocean-side community on LDI, several salt-tolerant or wetland species were occasionally encountered, including Argentina egedii, Bolboschoenus maritimus, Juncus balticus, J. gerardii, Plantago maritima, and Impatiens capensis (Figure 7). The LDI ocean-side community was also dominated by the abundant and frequent species found in its field community, followed by an abundance 


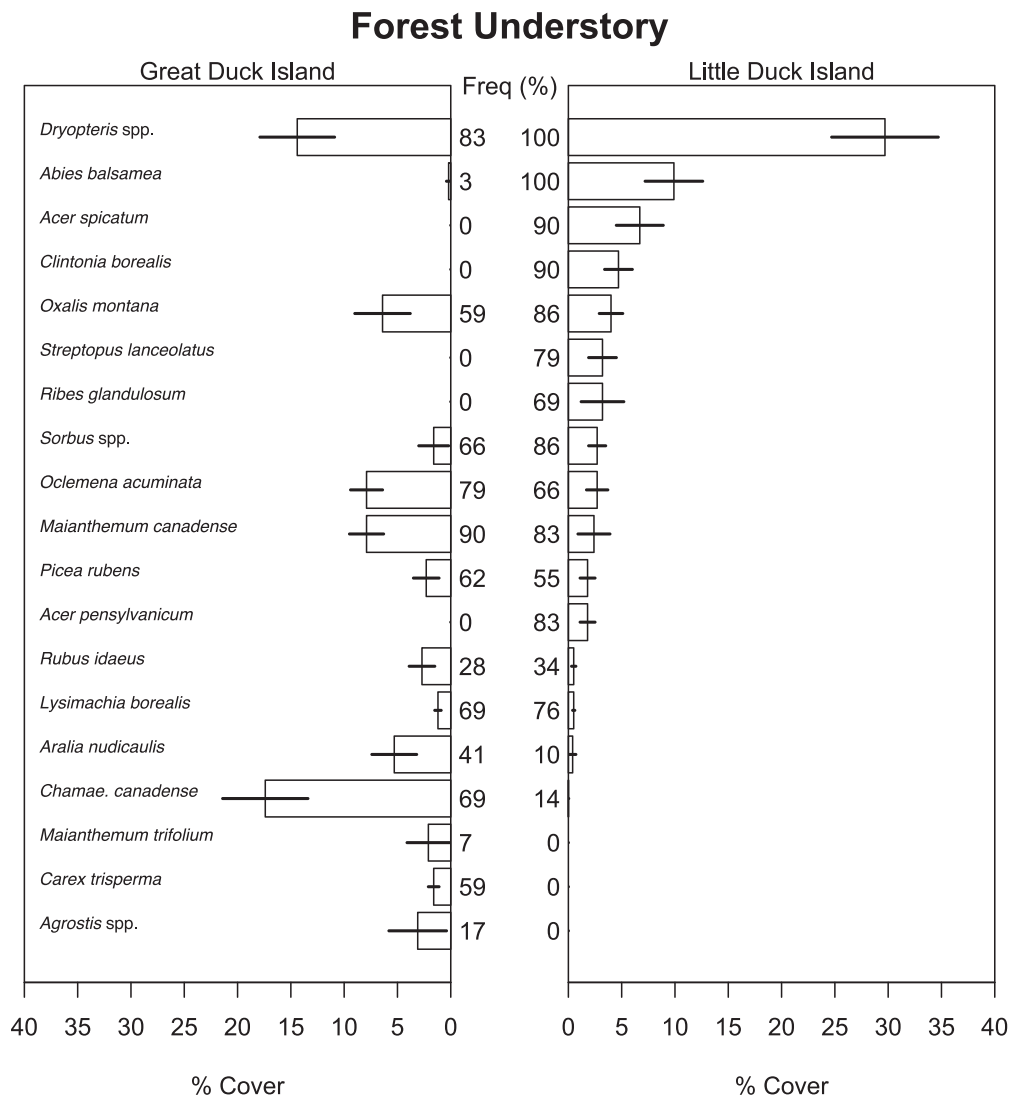

Figure 4. Forest community species with the 10 highest abundance and frequency ranks on Great Duck and Little Duck Islands, during summers 2010 2011. Abundance was determined as mean percent cover ( \pm SE). Frequency refers to the percent of plots on each island occupied by each species. Additional species were included to account for ties in abundance or frequency.

of Lathyrus japonicus, Elymus repens, Rubus idaeus, C. sepium, and Angelica lucida (Figure 7). A mean alpha diversity of $14( \pm 1.34)$ species was encountered in ocean-side plots on GDI, and a mean alpha diversity of $13.27( \pm 1.42)$ species was encountered in ocean-side plots on LDI (Table 2). See Table 2 for the Shannon-Wiener diversity index.

Soils. Visual inspection of soil PCA ordinations for each community indicated that LDI and GDI generally differed in their soil properties (Figure 8). The greater overall extent of GDI plots in multivariate 


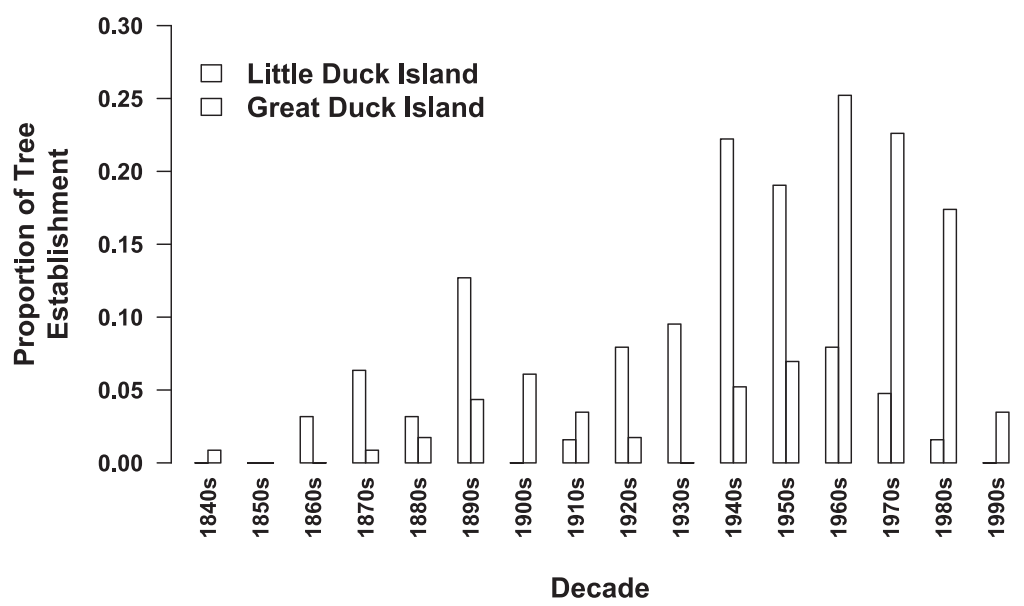

Figure 5. Tree recruitment history of Great Duck and Little Duck Islands. Tree ages were determined by coring all trees greater than $5 \mathrm{~cm} \mathrm{DBH}$ in plots and adding 10 to ring count to account for age at breast height. Tree age was then subtracted from 2010 (LDI) or 2011 (GDI) to determine recruitment decade ( $\mathrm{n}=115$ for LDI, $\mathrm{n}=63$ for GDI).

ordination space suggested that GDI generally had a greater variation in soil features between plots (Figure 3). The primary two PCA axes explained $60 \%$ of the variation in soil properties in forest soils, $66 \%$ of the variation in field soils, and $65 \%$ of the variation in ocean-side soils. The first axis of variation in forest soils was primarily driven by a gradient of physical properties related to $\mathrm{CEC}$, organic matter, and associated nutrient availabilities. The second axis of variation in forest soils explained more of the soil variation between GDI and LDI, and was primarily associated with $\mathrm{pH}$, nutrients, and soluble salts. Similar to forest soils, the first axis of variation in field soils was primarily driven by physical properties related to CEC, organic matter, and associated nutrient availabilities, whereas the second axis better differentiated between the islands and was driven by $\mathrm{pH}$ and essential nutrients. The first axis of variation in the ocean-side soils was similar to the first axis of other communities, but with the additional variation in soluble salts and $\mathrm{S}$. The second axis of variation in ocean-side soils was similar to field soils but with the addition of Mg. Overall, PCA results suggested that axes related to $\mathrm{pH}$ and essential nutrient concentrations best explained the variation between islands, though salinity and $\mathrm{S}$ were also important for differences between ocean-side soils of the islands. Through pairwise comparisons, we found $\mathrm{pH}$ to be higher on LDI in all three communities. 


\section{Field}

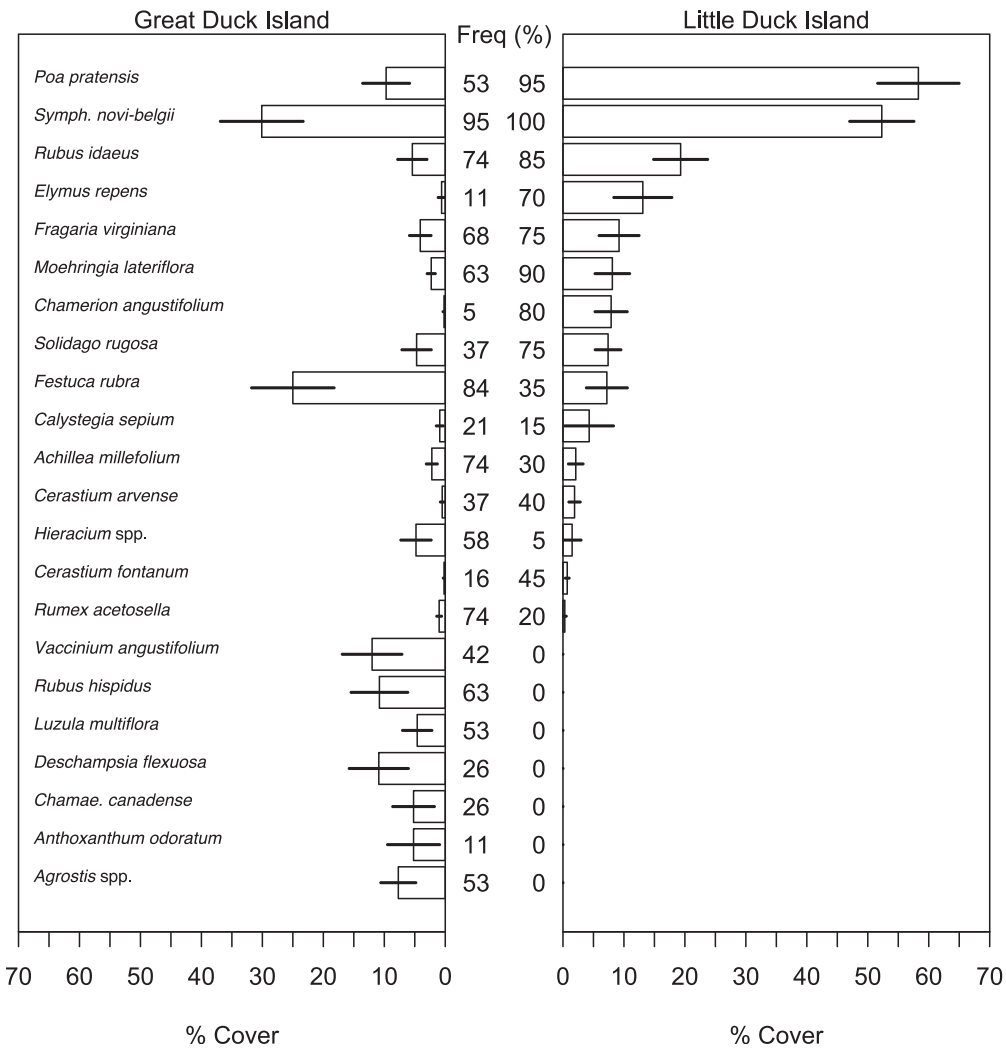

Figure 6. Field community species with the 10 highest abundance and frequency ranks on Great Duck and Little Duck Islands, during summers 2010 2011. Abundance is determined as mean percent cover ( \pm SE). Frequency refers to the percent of plots on each island occupied by each species. Additional species were included to account for ties in abundance or frequency.

In addition, $\mathrm{P}$ was higher on LDI in fields, $\mathrm{Ca}$ was higher in LDI forests, and $\mathrm{K}$ was higher in LDI ocean-side sites (Table 1). Soluble salt was higher in GDI forests and ocean-side communities (Table 1). No other soil features differed significantly between islands (Table 1).

\section{DISCUSSION}

Our study is among the first floristic studies of Maine's islands to generate baseline ecological information for vascular plant species 


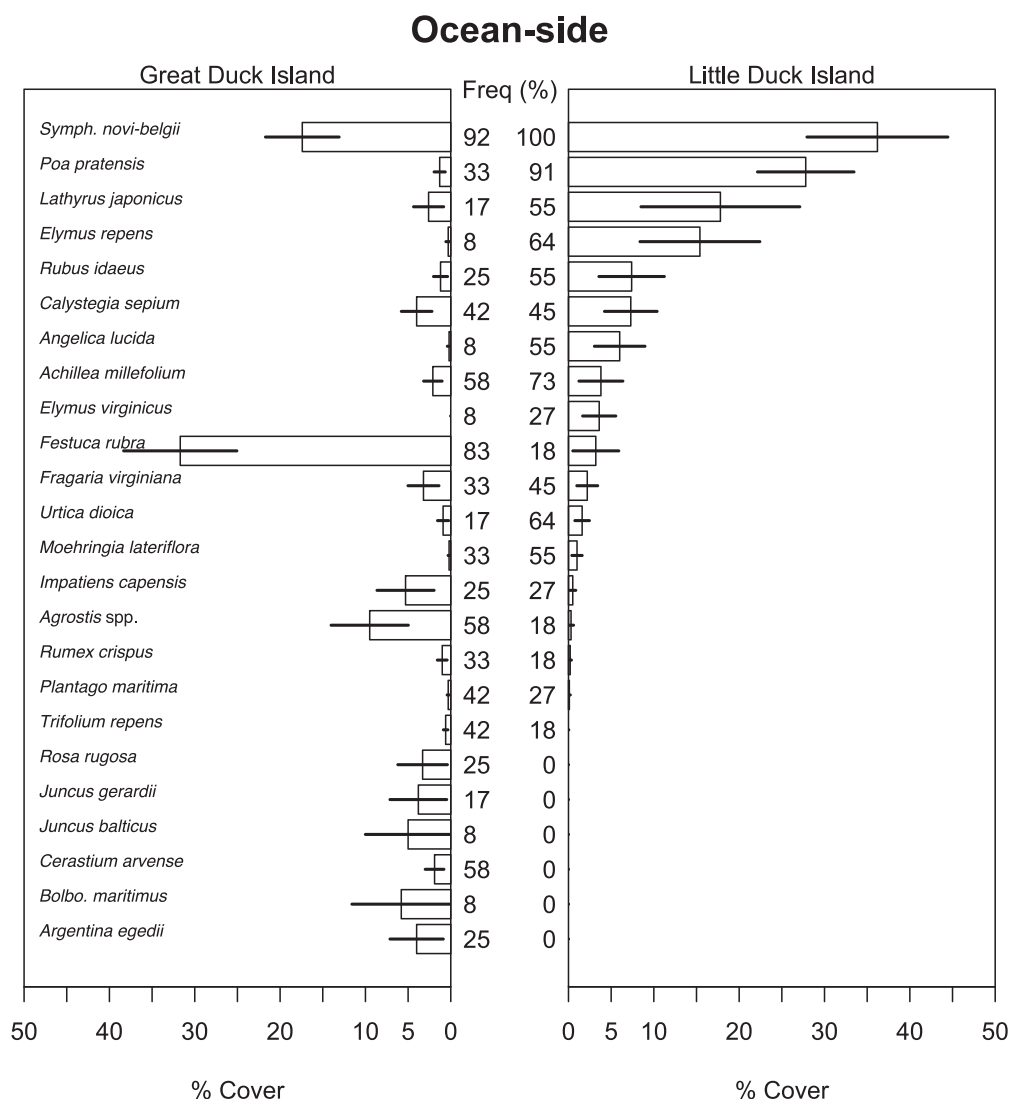

Figure 7. Ocean-side community species with the 10 highest abundance and frequency ranks on Great Duck and Little Duck Islands, during summers 2010 2011. Abundance is determined as mean percent cover ( \pm SE). Frequency refers to the percent of plots on each island occupied by each species. Additional species were included to account for ties in abundance or frequency.

diversity, abundance, and associated edaphic features. Our findings suggest that soil characteristics and the dominance and regeneration of vascular plant species can differ substantially, even between adjacent islands with otherwise similar geologic characteristics and glacial history. Differences in vegetation structure were especially apparent in the forest communities. The overstory on LDI was dominated by Abies balsamea and had a greater diversity of both coniferous evergreen and broad-leaf deciduous trees, despite the overall greater diversity of 


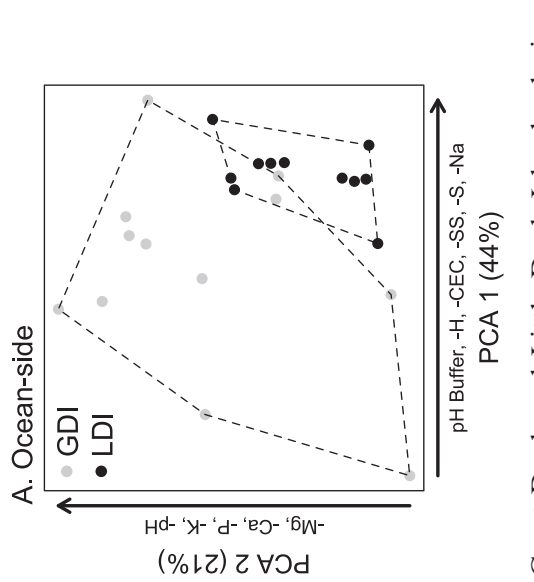

DD $\Xi \varangle$

竞离

के 들

求

능

渮

0 줌

정

$\exists \approx$

믈

त

论 胥

웧

政

0 边

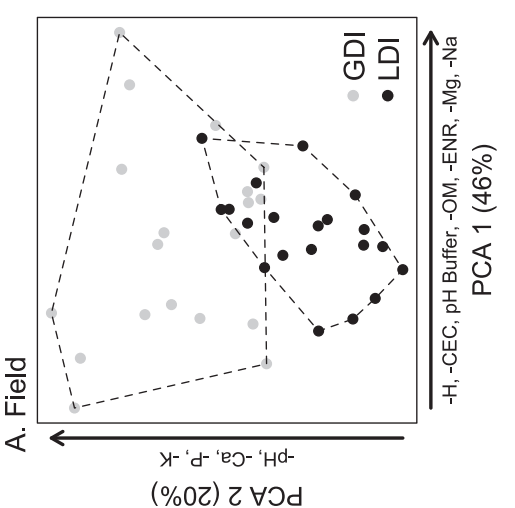

으

吸

苯芯客

范芯

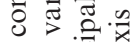

$\exists$ 记

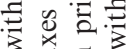

정

\&

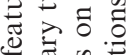

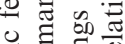

光 浔

충

웡 토은

पे

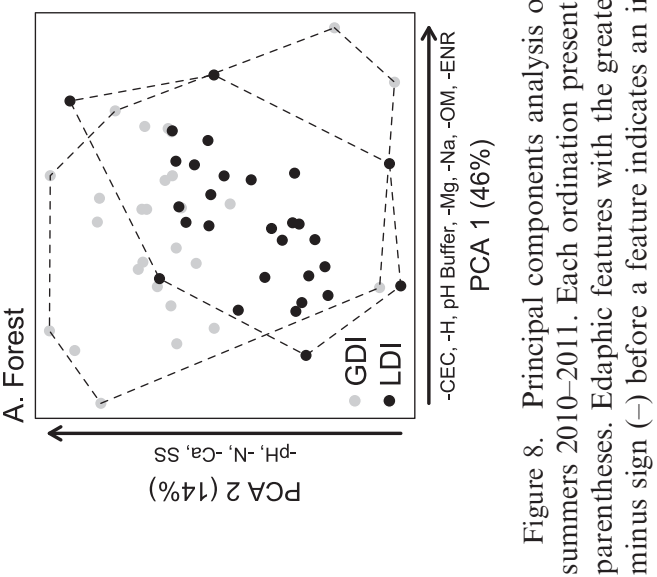


species on GDI. The historic recruitment of the overstory on LDI peaked more recently than on GDI, and the greater abundance of saplings on LDI suggests that, at the time of this study, the tree species found on this island were successfully regenerating. In contrast, the forest on GDI was almost exclusively dominated by Picea spp., which peaked in recruitment in the 1940s and for which few saplings were recorded in the current study. The overall significantly lower sapling count on GDI was evident even when accounting for differences in soil features.

A number of abiotic and biotic factors may have contributed to the documented vegetation and soils differences between LDI and GDI. For example, GDI has a maximum elevation of about $18 \mathrm{~m}$ compared to $27 \mathrm{~m}$ on LDI. The lower elevation on GDI could expose inland habitats to more salt spray. This can explain the significantly greater soluble salt concentrations in the forest and ocean-side community, and the greater diversity of halophyte (salt-tolerant) species in the oceanside community on GDI. It may also explain why Festuca rubra, a more salt-tolerant species than Poa pratensis (Torello and Symington 1984), was the dominant graminoid in the open communities on GDI. However, sapling counts in GDI forests were lower even when accounting for the edaphic differences.

Another factor that contributed to the vegetation differences is the land-use history of these islands. GDI has a long history of introduced mammalian herbivores, including at least $100 \mathrm{y}$ of sheep and $60 \mathrm{y}$ of European and Snowshoe hares, compared to LDI, which has been largely free of mammalian herbivores for at least the last $100 \mathrm{y}$ (McLane 1989). Mammalian herbivores can have drastic impacts on plant communities (Crawley 1997; Donlan et al. 2002; McLaren et al. 2004; Nunez et al. 2010; Peterson et al. 2005; Terborgh et al. 2001), so it seems plausible that the long-term history of mammalian habitation on GDI could have played a role in the vegetation and soil differences between these islands. Herbivory may shift the composition of plant species through preferential browsing and grazing of more palatable or noticeable species. Over time, this can lead to communities composed of species that are more tolerant, or less palatable, to herbivores (Díaz et al. 2001; Gillham 1955; McInnes et al. 1992). For example, Clintonia borealis and Streptopus lanceolatus have been shown to be particularly vulnerable to mammalian herbivory (Balgooyen and Waller 1995; Kraft et al. 2004; Lapointe et al. 2010), which suggests why these species may be lacking on GDI, though frequently encountered in plots on LDI. 


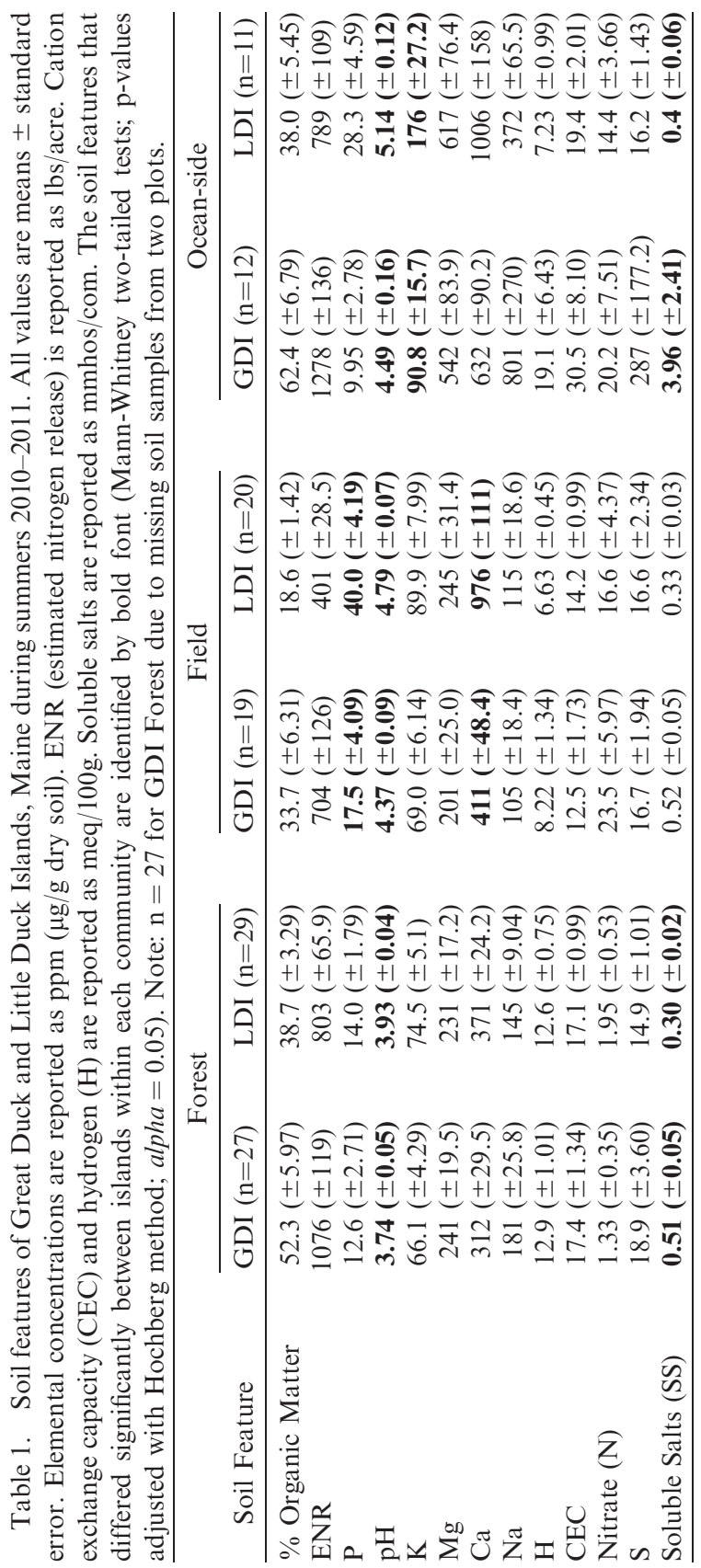




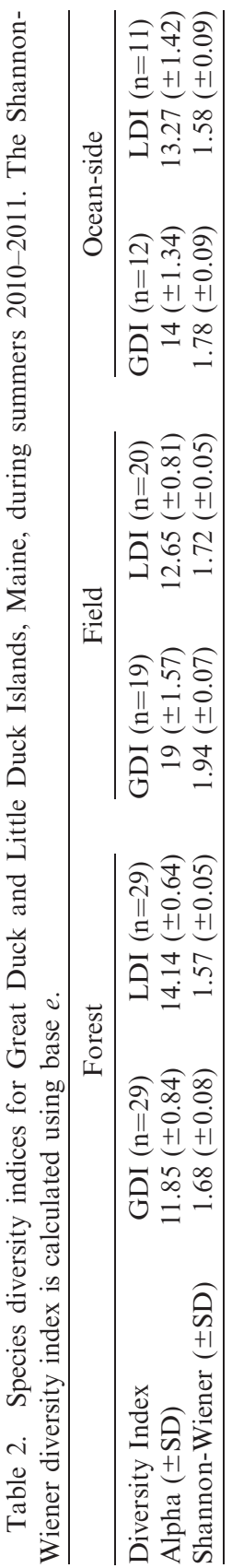


Herbivory can also affect forest succession by, directly or indirectly, suppressing or supporting the growth of certain woody species (Angell and Kielland 2009; Heinen and Currey 2000; McInnes et al. 1992; Peterson et al. 2005). Betula papyrifera was the primary regenerating species in forests on GDI, congruent with a study that found young $B$. papyrifera individuals to be more resistant to snowshoe hare herbivory by reducing palatability through a high resin content in juvenile twigs (Bryant et al. 1983). Almost no Picea spp. recruitment was encountered on GDI, consistent with a study comparing forest regeneration on two Maine islands that differed in long-term snowshoe hare herbivory (Peterson et al. 2005). This study concluded that hares were actively inhibiting the regeneration of northern spruce-fir forest through seedling browsing, reflected by a decline in tree recruitment following the introduction of the hares. We found a similar result with our histogram of tree recruitment on the Duck Islands over the last century, in which tree recruitment on GDI has declined since the introduction of hares in the 1940s (Figure 5). Lacking a better alternative hypothesis, we suggest the reduced sapling regeneration and decline in tree recruitment on GDI is due to the introduction of hares. However, future experimental work (i.e., long-term hare exclosures that track regenerating individuals to maturity) is necessary for directly testing this hypothesis (Clark et al. 1999). This is because the effect of herbivory on plant community succession may be highly context dependent - in some cases accelerating woody succession (Davidson 1993).

Vegetation differences may also be driven by soil processes, in some cases, to a greater extent than by herbivory (Turkington et al. 2002). This may be especially important when extrinsic factors such as nesting seabirds drive essential nutrient and heavy metal concentrations in the soil (Ellis 2005; Rajakaruna et al. 2009). Essential nutrient concentrations of $\mathrm{P}$ and $\mathrm{Ca}$ were about two-fold greater in the field community on LDI, and $\mathrm{K}$ was about two-fold greater in the ocean-side community on LDI. This may reflect a longer history of seabird nesting on LDI, which would lead to an increase in nutrient concentrations (Ellis 2005). Finally, the plants are key drivers of soil properties, and feedbacks make it impossible to distinguish cause from effect without adequate experimental data (Chapin et al. 2011).

Little Duck Island and GDI also differ in other aspects of their landuse history. Humans have not inhabited LDI over the last century, whereas GDI had at least three families with multiple dwellings, including a schoolhouse for thirty children, at its peak habitation in the early 20th century (McLane 1989). Although the primary human 
impact may be directly linked to grazing by introduced sheep and browsing by introduced hares, localized agricultural plots, trail compaction, an airplane landing strip, and timber harvest may have also had important impacts on the soils and vegetation of GDI. Timber harvest may have influenced the tree demography by removing certain age classes and reducing the diversity of hardwoods in the canopy (Figures 2, 5). Human habitation of GDI has largely declined over the last century and especially, since 1986, when the lighthouse became automated. Thus, it seems unlikely that human history had a confounding influence on the most recent decline in tree recruitment. Those trees would have likely been too young to be worth harvesting until at least the 1970s and, by then, human habitation had declined. Furthermore, any human impact by trail compaction, localized agriculture, or the airplane landing strip is unlikely to be evident in our plot data since we avoided placing plots in areas with evident human disturbance. Overall species lists for the Duck Islands, however, may reflect some of these human effects. For example, several species of orchids such as Malaxis unifolia and Platanthera clavellata were found growing on the airplane landing strip on GDI and were otherwise absent from the rest of the island. Finally, it is important to acknowledge prehistoric differences in human-use between GDI and LDI and the potential impacts of shell middens on soil nutrients and vegetation structure (Cook-Patton et al. 2014). Future work may consider available archaeologic history as an additional factor.

Repeated resurveys are important for gauging long-term changes in communities and ecosystems, though it would be important that a similar survey effort be made in order to yield comparable results. Most earlier surveys of the Duck Islands were not as thorough as the current study (but see Folger and Wayne 1986). For example, efforts by Redfield $(1885,1893)$ and Rand (1900) were based on single- or severalday surveys and, by Rappaport and Wesley (1985), on only five days. Lesser (1977) did not include any graminoids or other cryptic species. Thus, the extant surveys are not ideal for drawing conclusions about factors contributing to any documented changes. Nonetheless, some interesting anecdotes may be gleaned from historic surveys. For example, Capsella bursa-pastoris, an otherwise common ruderal species, was not encountered in the current study of the Duck Islands, yet it was commonly recorded on both islands in historic surveys of lesser effort. The disappearance of C. bursa-pastoris suggests the potential role of stochastic population drift in communities (Vellend 2010), especially as it may affect short-lived species such as C. bursa-pastoris on islands. Overall, 73 species were historically recorded but not found in the 
current survey, which supports the idea of the dynamic nature of island community turnover as described by MacArthur and Wilson's (1967) theory of island biogeography (but see Nilsson and Nilsson 1983). Future resurveys should also include quantitative records of species abundances in order to gauge relevant changes in ecosystem properties that are otherwise lost in the coarse scale of basic floristic surveys.

Limitations of the study. We chose to avoid plant-community transition zones in our vegetation survey. Although this approach was necessary for characterizing particular plant communities, it ignores the unique characteristics of the transition zones. Several species were most common in the transition zone between forest and field, rather than in either community. These, and other species missed in plots, were captured on the total species list (Appendix). The transition between forest and field may also harbor a greater number of regenerating trees due to proximity to seed sources and increased light availability, though such data were unavailable from our study. Although our plot design does not account for all regeneration, composition, and diversity of each island, it does offer data that are comparable between these and, hopefully, future island surveys.

Our study is among the first to incorporate edaphic features and vascular plant species abundances into a robust baseline description of island ecosystems in the Gulf of Maine (but see Rajakaruna et al. 2009). Our study provides an important baseline from which to gauge future changes in coastal Maine habitats, and our causal understanding of island ecosystems will increase as more surveys are conducted and their data made available. We suggest that future island inventories incorporate plot surveys to estimate the abundance of plant species, as well as to quantify associated edaphic properties. Such baseline data and future re-surveys will be essential for better understanding the potential direct and indirect effects of climate change, rising sea levels, herbivory, and other human impacts.

ACKNOWLEDGMENTS. We thank Kaija Klauder for her field assistance with island surveys. We also thank Chris Petersen for advice and feedback on the design of this study, and Robert S. Boyd, Robert S. Capers, and two anonymous reviewers for helpful comments on earlier drafts of this paper. We thank John Anderson, College of the Atlantic, and the Alice Eno Research Station on Great Duck Island for lodging and accommodation during fieldwork. We thank Trent Quimby and Scott Swann for boat transportation. We also thank Arthur Haines, Jill Weber, Sal Rooney, Jordan Chalfant, David Werier, Rick Fournier, Bill Moorhead, and Eric Doucette for help with plant specimen 
identification. Finally, we are grateful to the National Audubon Society, Acadia National Park, College of the Atlantic, and The Nature Conservancy for permission to conduct fieldwork on the Duck Islands. This study was supported by Maine Space Grant Consortium summer fellowships and Garden Club of America field botany grants to M. Dickinson and L. Negoita, and was completed in fulfillment of the College of the Atlantic senior project graduation requirement by L. Negoita.

\section{LITERATURE CITED}

Allen, B., G. H. Mittelhauser, L. Welch, R. Houston, R. Schauffler, And M. LANGLoIs. 2012. Maine atlas of breeding seabird and coastal wading bird colonies - 1960 to 2011. Maine Natural History Observatory, Gouldsboro, ME.

Angell, A. C. And K. Kielland. 2009. Establishment and growth of white spruce on a boreal forest floodplain: Interactions between microclimate and mammalian herbivory. Forest Ecol. Managem. 258: 2475-2480.

Balgooyen, C. P. And D. M. WAller. 1995. The use of Clintonia borealis and other indicators to gauge impacts of white-tailed deer on plant communities in northern Wisconsin, USA. Nat. Areas J. 15: 308-318.

Barnhardt, W. A., W. R. Gehreis, D. F. Belknap, and J. T. Kelley. 1995. Late Quaternary relative sea-level change in the western Gulf of Maine: Evidence for a migrating glacial forebulge. Geology 23: 317-320.

Bryant, J., F. S. Chapin III, AND D. Klein. 1983. Carbon/nutrient balance of boreal plants in relation to vertebrate herbivory. Oikos 40: 357-368.

Campbell, C. S., H. P. Adams, P. Adams, A. C. Dibble, L. M. Eastman, S. C. GAWLER, ET AL. 1995. Checklist of vascular plants of Maine, 3rd revis. Bull. 844, Maine Agricultural and Forest Experiment Station, Orono, ME.

Caujapé-Castells, J., A. Tye, D. J. Crawford, A. Santos-Guerra, A. Sakai, K. BeAver, et AL. 2010. Conservation of oceanic island floras: Present and future global challenges. Perspect. Pl. Ecol. Evol. Syst. 12: 107-129.

Chapin, F. S. III, P. A. Matson, and P. Vitousek. 2011. Principles of Terrestrial Ecosystem Ecology. Springer-Verlag, New York, NY.

Clark, J., B. Beckage, P. Camill, B. Cleeveland, J. HilleRislambers, and J. LiCHTER. 1999. Interpreting recruitment limitation in forests. Amer. J. Bot. 86: $1-16$.

Clayden, S. R., M. C. Munro, C. S. Blaney, and S. P. Vander Kloet. 2010. Vascular flora of the Atlantic maritime ecozone: Some new perspectives, pp. 197-213. In: D. F. McAlpine and I. M. Smith., eds., Assessment of Species Diversity in the Atlantic Maritime Ecozone. NRC Research Press, Ottawa, Canada.

Conkling, P. 2011. Islands in Time: A Natural and Cultural History of Islands in the Gulf of Maine, 3rd ed. Island Institute, Rockland, ME.

Cook-Patton, S. C., D. Weller, T. C. Rick, and J. D. Parker. 2014. Ancient 
experiments: Forest biodiversity and soil nutrients enhanced by Native American middens. Landscape Ecol. 29: 979-987.

Crawley, M. J. 1997. Plant-herbivore dynamics, pp. 401-474. In: M. J. Crawley, ed., Plant Ecology, 2nd ed. Wiley-Blackwell, Oxford, UK.

DAvidson, D. A. 1993. The effects of herbivory and granivory on terrestrial plant succession. Oikos 68: 23-35.

Davis, R. B. R. 1966. Spruce-fir forests of the coast of Maine. Ecol. Monogr. 36: 79-94.

Díaz, S., I. Noy-Meir, and M. Cabido. 2001. Can grazing response of herbaceous plants be predicted from simple vegetative traits? J. Appl. Ecol. 38: 497-508.

Donlan, C. J., B. R. Tershy, and D. Croll. 2002. Islands and introduced herbivores: Conservation action as ecosystem experimentation. J. Appl. Ecol. 39: 235-246.

Ellis, J. 2005. Marine birds on land: A review of plant biomass, species richness, and community composition in seabird colonies. Pl. Ecol. 181: 227-241.

Ellis, J. C., J. M. Farina, And J. D. Witman. 2006. Nutrient transfer from sea to land: The case of gulls and cormorants in the Gulf of Maine. J. Anim. Ecol. 75: 565-574.

, P. J. Bellingham, E. K. Cameron, D. A. Croll, G. S. Kolb, C. Kueffer, G. H. Mittelhauser, S. Schmidt, E. Vidal, and D. A. Wait. 2011. Effects of seabirds on plant communities. pp. 177-211. In: C. P. H. Mulder, W. B. Anderson, D. R. Towns, and P. J. Bellingham, eds., Seabird Islands: Ecology, Invasion, and Restoration. Oxford University Press, Oxford, UK.

Folger, D. C. And P. M. Wayne. 1986. A biological inventory of Great Duck Island: Hancock County, Maine. The Nature Conservancy, Arlington, VA.

Gawler, S. And A. Cutko. 2010. Natural Landscapes of Maine: A Guide to Natural Communities and Ecosystems. Maine Natural Areas Program, Department of Conservation, Augusta, ME.

Gillham, M. E. M. 1955. Ecology of the Pembrokeshire Islands. III. The effect of grazing on the vegetation. J. Ecol. 43: 172-206.

Greene, C. W., L. L. Gregory, G. H. Mittelhauser, S. C. Rooney, and J. E. Weber. 2005. Vascular flora of the Acadia National Park region, Maine. Rhodora 107: 117-185.

Haines, A. 2011. Flora Novae Angliae. Yale University Press, New Haven, CT.

Harris, T. B., N. Rajakaruna, S. J. Nelson, and P. D. Vaux. 2012. Stressors and threats to the flora of Acadia National Park, Maine: Current knowledge, information gaps, and future directions. J. Torrey Bot. Soc. 139: 323-344.

Heinen, J. T. and R. C. D. Currey. 2000. A 22-year study on the effects of mammalian browsing on forest succession following a clearcut in northern Lower Michigan. Amer. Midl. Naturalist 144: 243-252. 
HochberG, Y. 1988. A sharper bonferroni procedure for multiple tests of significance. Biometrika 75: 800-802.

Hodgdon, A. R. And R. B. Pike. 1969. Floristic comparison of three bird islands in the Gulf of Maine. Rhodora 71: 510-523.

IRLAND, L. C. 1997. Maine's forest vegetation regions: Selected maps 858-1993 N. E. Naturalist 4: 241-260.

Jordan, G. B. 1988. Soil Survey of Hancock County Area, Maine. U.S. Department of Agriculture, Natural Resource Conservation Service. Augusta, ME.

Kraft, L. S., T. R. Crow, D. S. Buckley, E. Nauertz, and J. C. Zasada. 2004. Effects of harvesting and deer browsing on attributes of understory plants in northern hardwood forests, Upper Michigan, USA. Forest Ecol. Managem. 199: 219-230.

Lapointe, L., J. Bussières, M. Crête, and J. P. Ouellet. 2010. Impact of growth form and carbohydrate reserves on tolerance to simulated deer herbivory and subsequent recovery in Liliaceae. Amer. J. Bot. 97: 913-924.

Lesser, E. A. 1977. A study of maritime birds on Little Duck Island, Maine. Senior project report. College of the Atlanic, Bar Harbor, ME.

Lewis, A. J. 1983. Distribution of three rare plants on islands in Machias Bay, ME. Rhodora 85: 385-388.

MacArthur, R. H. and E. O. Wilson. 1967. The Theory of Island Biogeography. Monographs in Population Biology. Princeton University Press, Princeton, NJ.

Mcinnes, P., R. Naiman, and J. Pastor, and Y. Cohen. 1992. Effects of moose browsing on vegetation and litter of the boreal forest, Isle Royale, Michigan, USA. Ecology 73: 2059-2075.

McLane, C. B. 1989. Islands of the Mid-Maine Coast. Vol. 2. Mount Desert to Machias Bay. The Kennebec River Press, Inc., Falmouth, ME.

McLaren, B. E., B. A. Roberts, N. Djan-Chekar, and K. P. Lewis. 2004. Effects of overabundant moose on the Newfoundland landscape. Alces 40: $45-59$.

McMahon J. S. 1990. Biophysical Regions of Maine. State Planning Office, Augusta, ME.

McMaster, R. T. 2005. Factors influencing vascular plant diversity on 22 islands off the coast of eastern North America. J. Biogeogr. 32: 475-492.

Mulligan, A. D. 1980. The flora, vegetation, and phytogeographic relationships of Whaleboat Island, Casco Bay, Maine. Rhodora 82:441459.

Nichols, W. F. And V. C. Nichols. 2008. The land use history, flora, and natural communities of the Isles of Shoals, Rye, New Hampshire and Kittery, Maine. Rhodora 110: 245-295.

Nilsson, S. G. AND I. N. Nilsson. 1983. Are estimated species turnover rates on islands largely sampling errors? Amer. Naturalist 121: 595-597.

North American Proficiency Testing Program (NAPT). 2011. Recommended Soil Testing Procedures for the Northeastern United States, 3rd ed. Soil 
Science Society of America, Madison, WI. Website (www.naptprogram. org/methods). Accessed February 2015.

Nunez, M., J. K. Bailey, And J. Schweitzer. 2010. Population, community, and ecosystem effects of exotic herbivores: A growing global concern. Biol. Invas. 12: 297-301.

Osberg, P. H., A. M. Hussey II, And G. M. Boone. 1985. Bedrock geologic map of Maine. Maine Geological Survey, Augusta, ME.

Peterson, T. S., A. Uesugi, and J. Lichter. 2005. Tree recruitment limitation by introduced Snowshoe Hares, Lepus americanus, on Kent Island, New Brunswick. Canad. Field-Naturalist 119: 569-572.

Pike, R. B. And A. R. Hodgdon. 1962. Changes in flora of the Machias Seal Islands. Rhodora 64: 340-346.

Rajakaruna, N., N. Pope, J. Perez-Orozco, and T. B. Harris. 2009. Ornithocoprophilous plants of Mount Desert Rock, a remote birdnesting island in the Gulf of Maine, U.S.A. Rhodora 111: 417-447.

Rand, E. L. 1900. Plants from the Duck Islands, Maine. Rhodora 2: 207-209.

RAPPAPORt, N. R., And F. R. Wesley. 1985. A vegetation study of nine bird islands off the Coast of Maine. National Audubon Society Report, Falmouth, ME.

R Development Core Team. 2014. R: A language and environment for statistical computing. R Foundation for Statistical Computing, Vienna, Austria.

Redfield, J. H. 1885. Insular vegetation. Bull. Torrey Bot. Club 12: 103. 1893. Botanical notes. Bull. Torrey Bot. Club 20: 409-410.

Stebbins, G. L., JR. 1929. Further additions to the Mt. Desert Flora. Rhodora 31: 81-87.

Terborgh, J., L. Lopez, P. Nunez, M. Rao, G. Shahabuddin, G. Orihuela, et AL. 2001. Ecological meltdown in predator-free forest fragments. Science 294: 1923-1926.

Torello, W. A. And A. G. Symington. 1984. Screening of turfgrass species and cultivars for $\mathrm{NaCl}$ tolerance. Pl. \& Soil 82: 155-161.

Turcotte, D. E. And T. H. Butler Jr. 2006. Folists and humods off the coast of eastern Maine. Soil Survey Horizons 47: 5-9.

Turkington, R., E. John, S. Watson, and P. Seccombe-Hett. 2002. The effects of fertilization and herbivory on the herbaceous vegetation of the boreal forest in north-western Canada: A 10-year study. J. Ecol. 90: 325-337.

US Climate Data. 2015. Historic climate data, Mount Desert, Maine. US Climate Data, version 2.2 beta. Website (http://www.usclimatedata.com/ climate/mount-desert/maine/united-states/usme0688/2015/1). Accessed July 2015.

Vellend, M. 2010. Conceptual synthesis in community ecology. Quart. Rev. Biol. 85: 183-206.

Wherry, E. T. 1926. Nitrogen as a factor in plant distribution on Mt. Desert Island, Maine. Ecology 7: 140-142.

Wise, D. A. 1970. The flora of Isle au Haut, Maine. Rhodora 72: 505-532. 


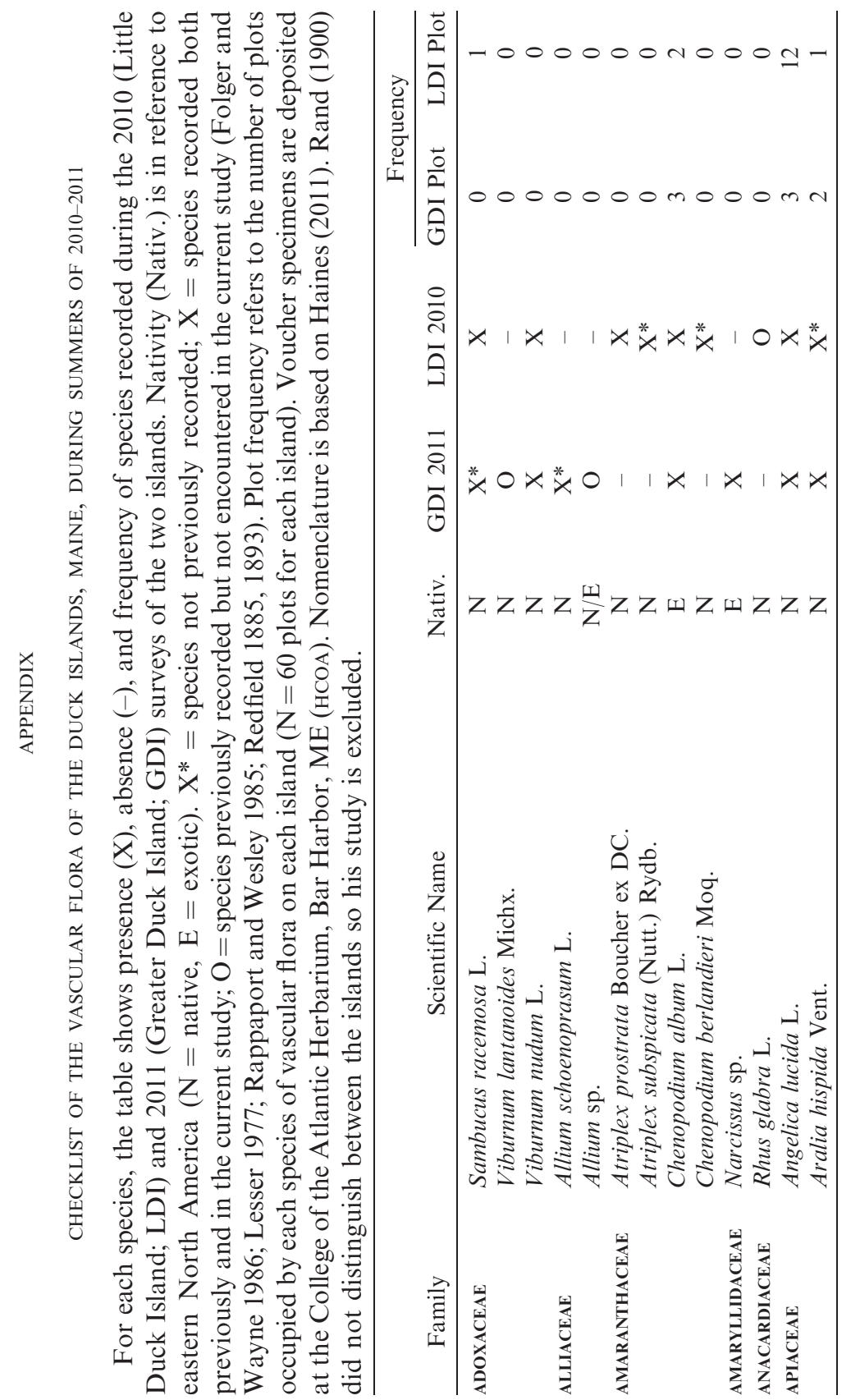




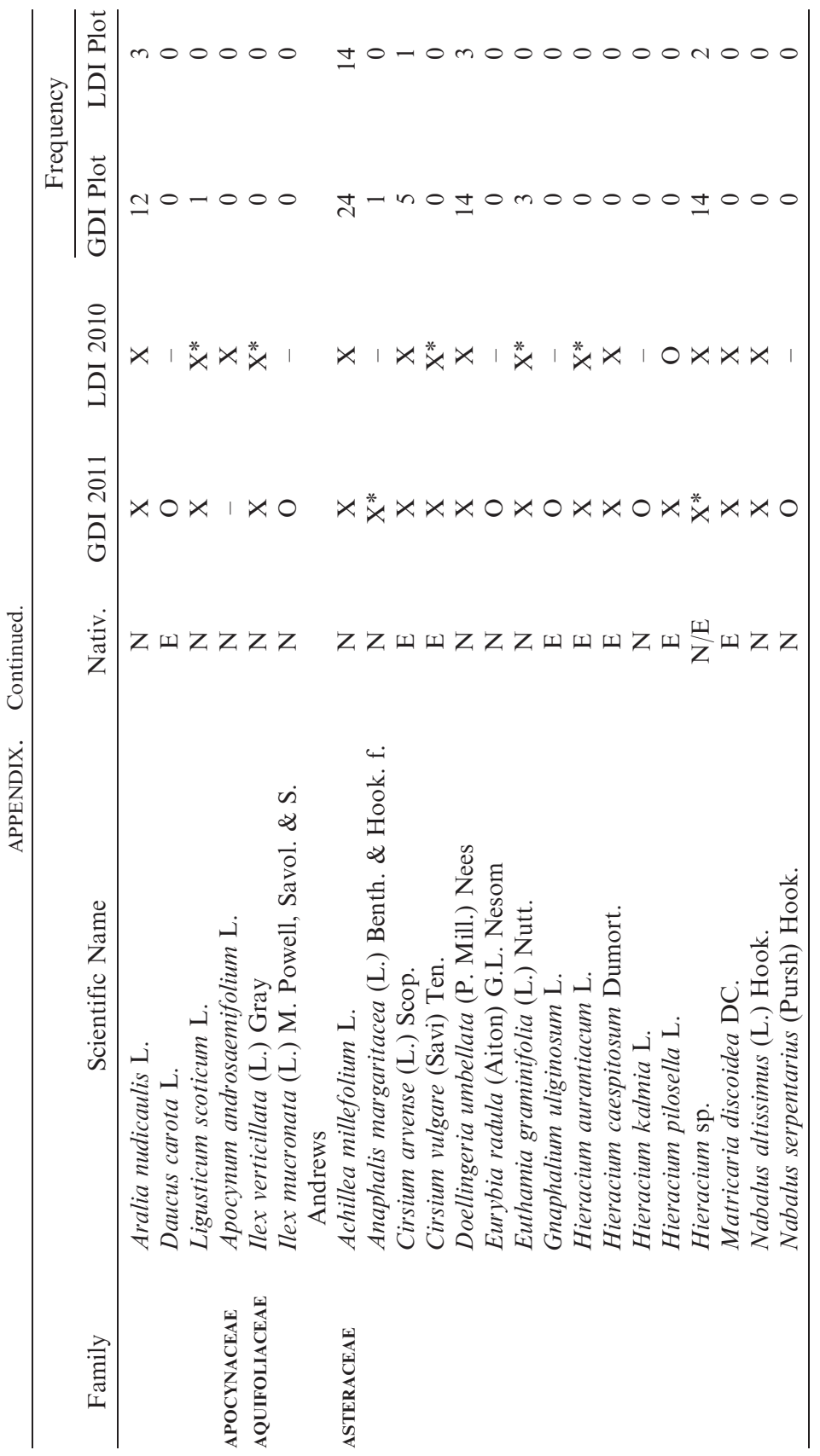




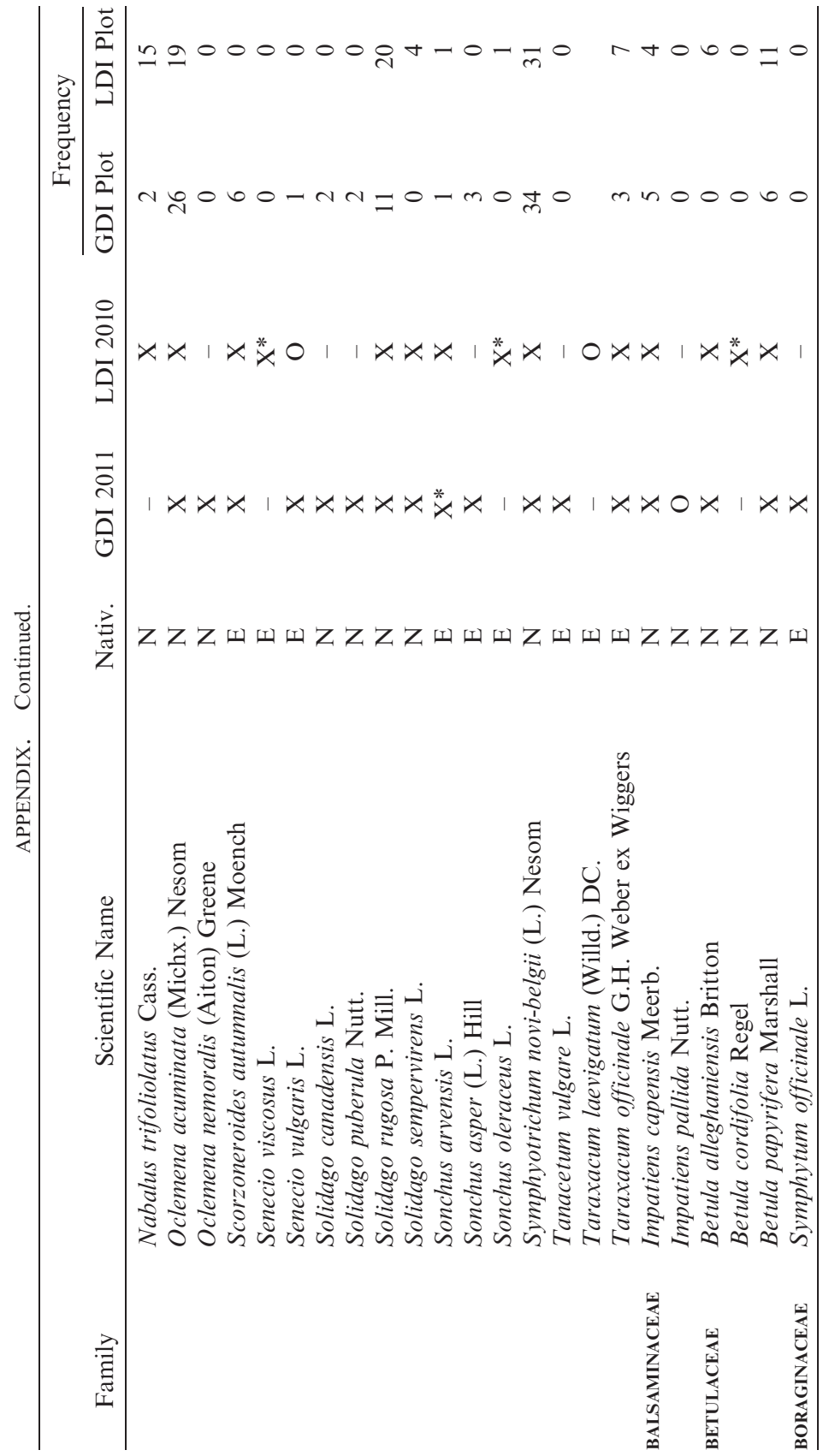




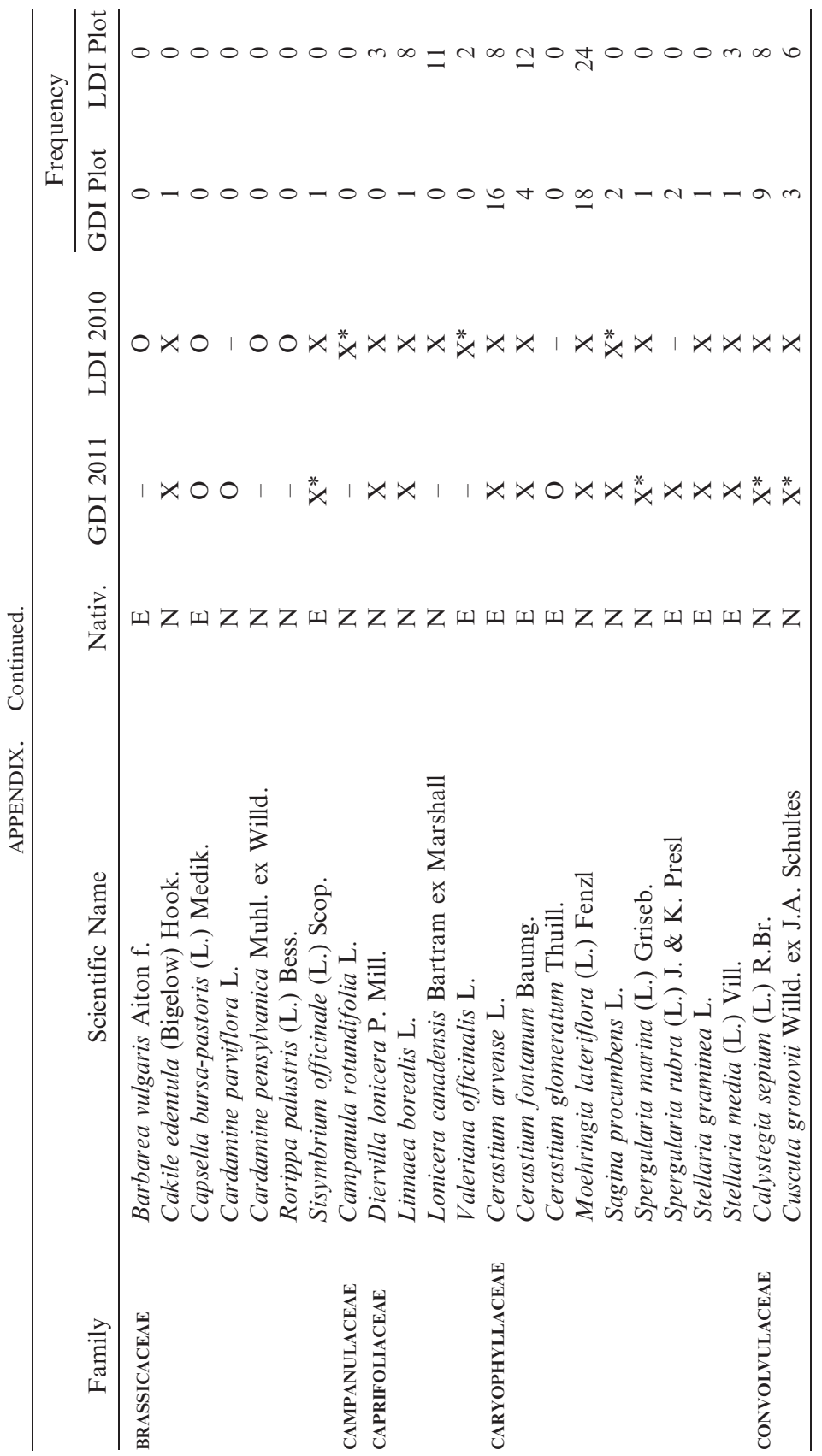




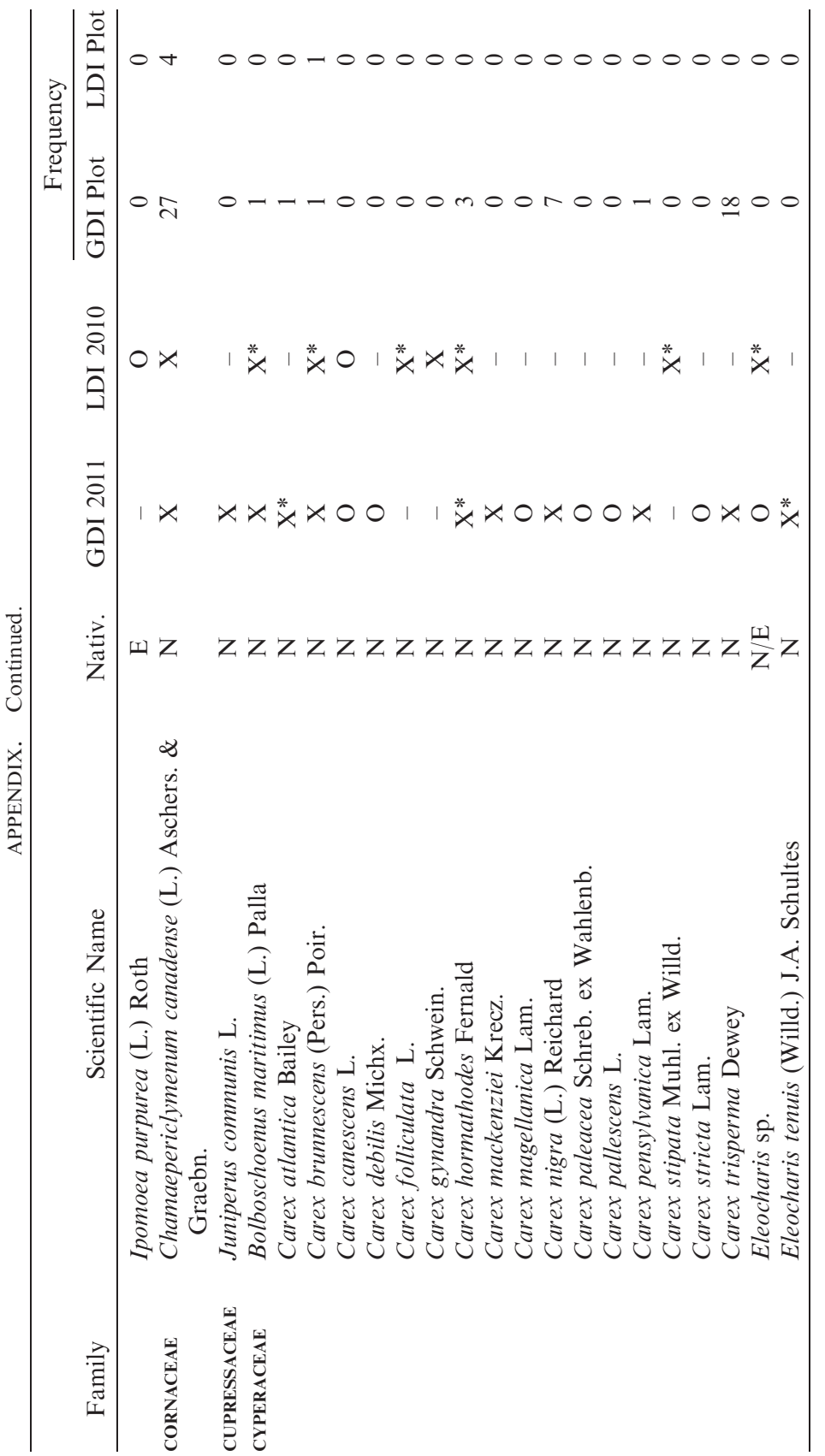




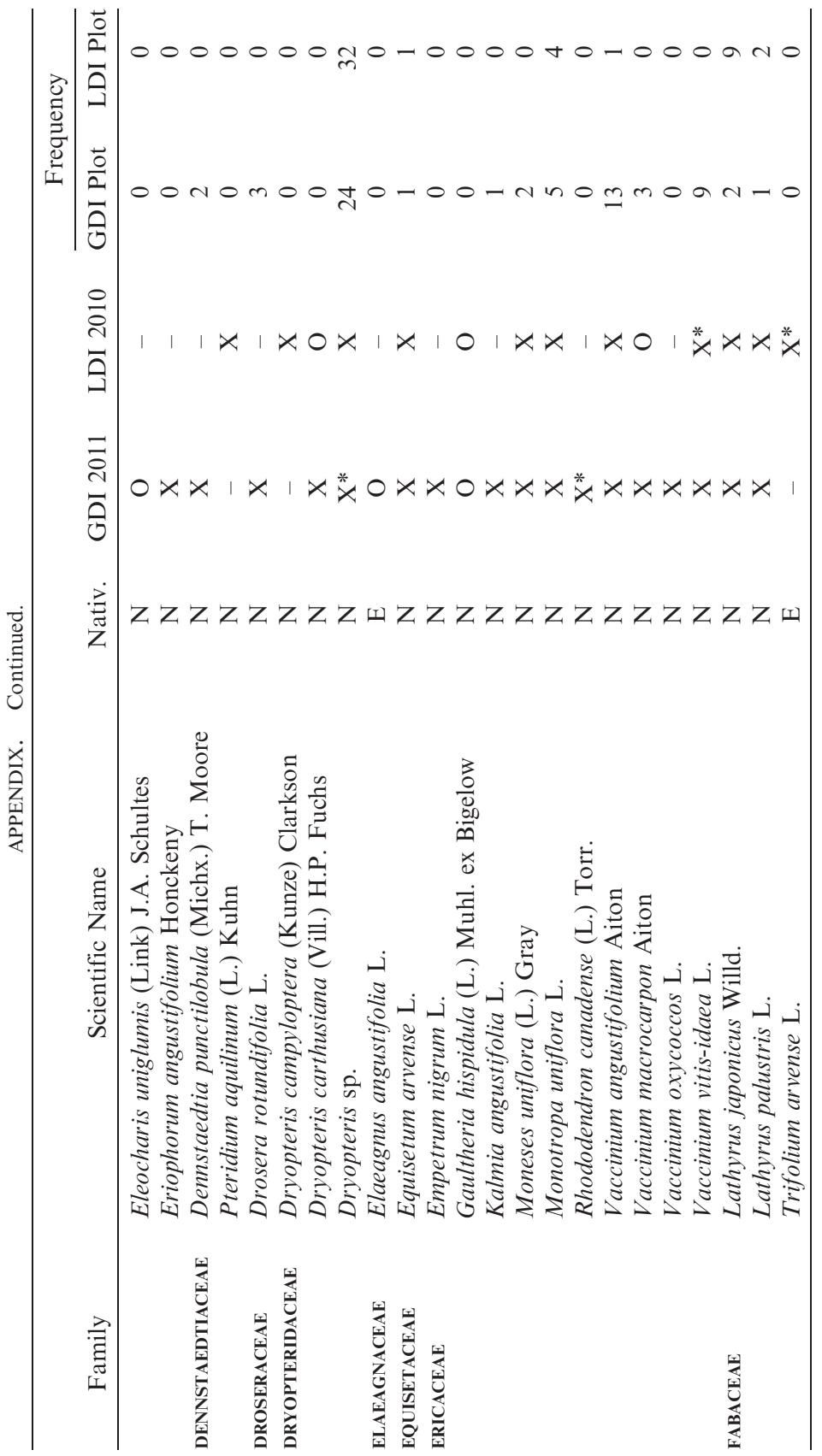




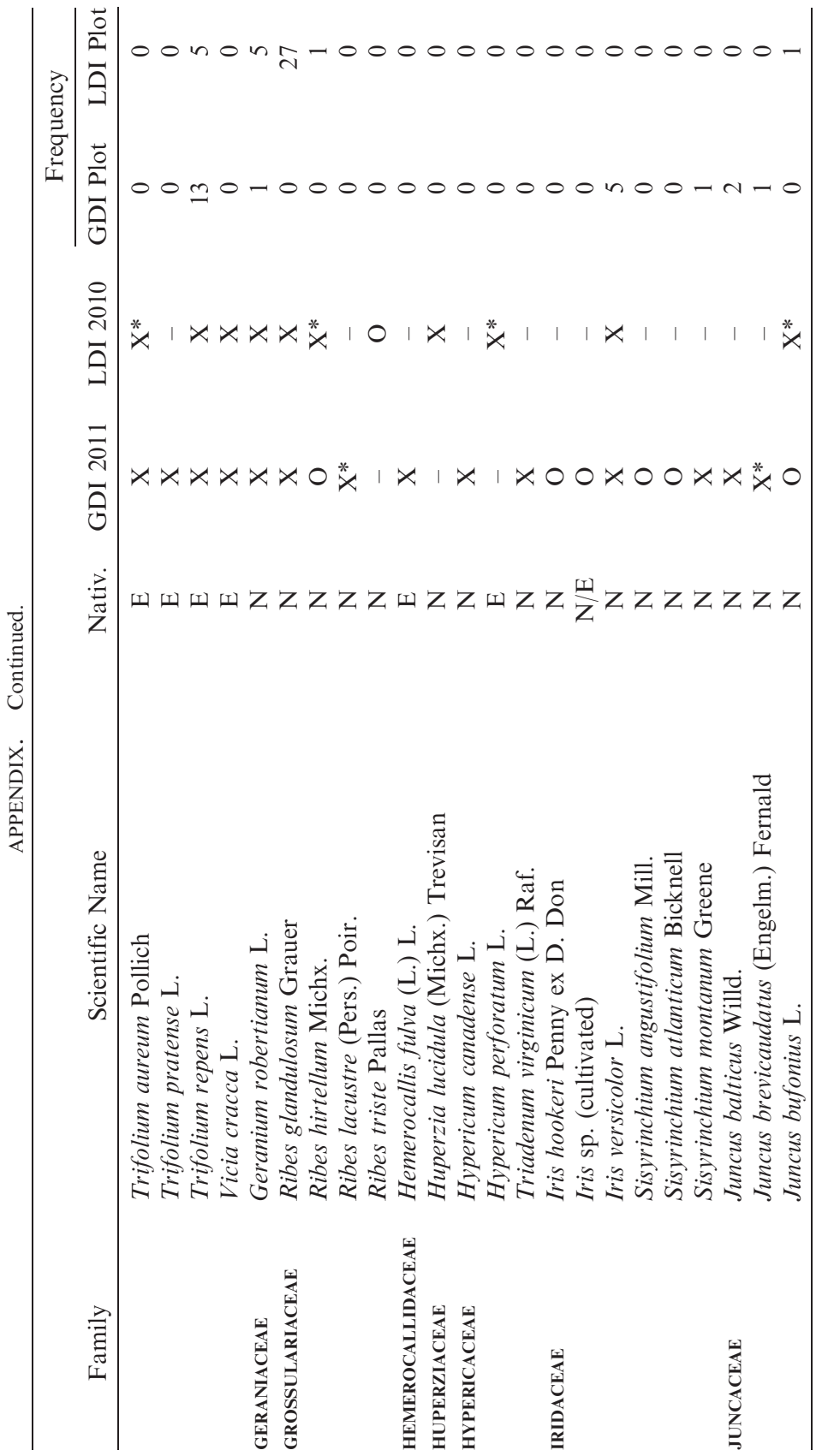




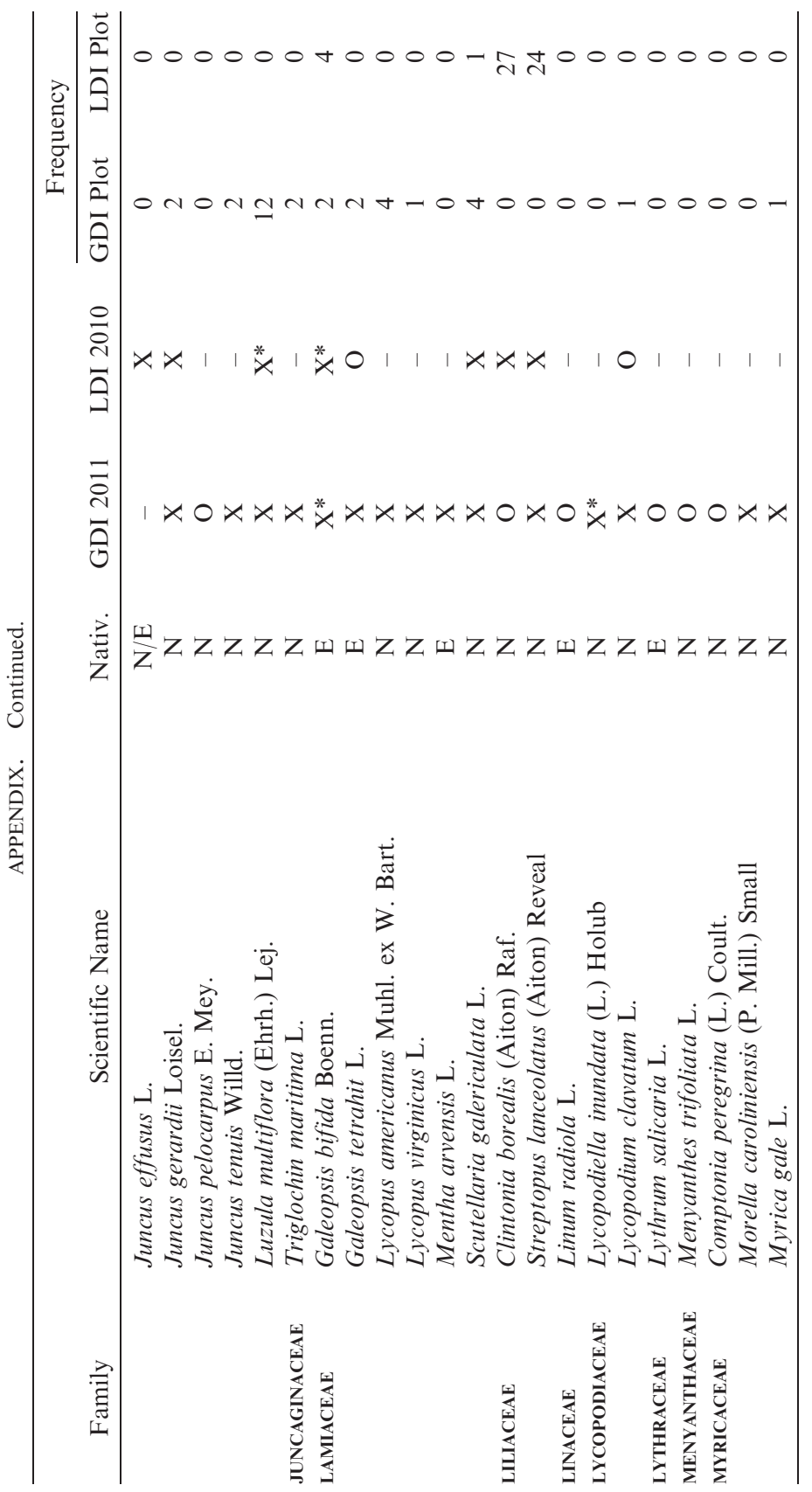




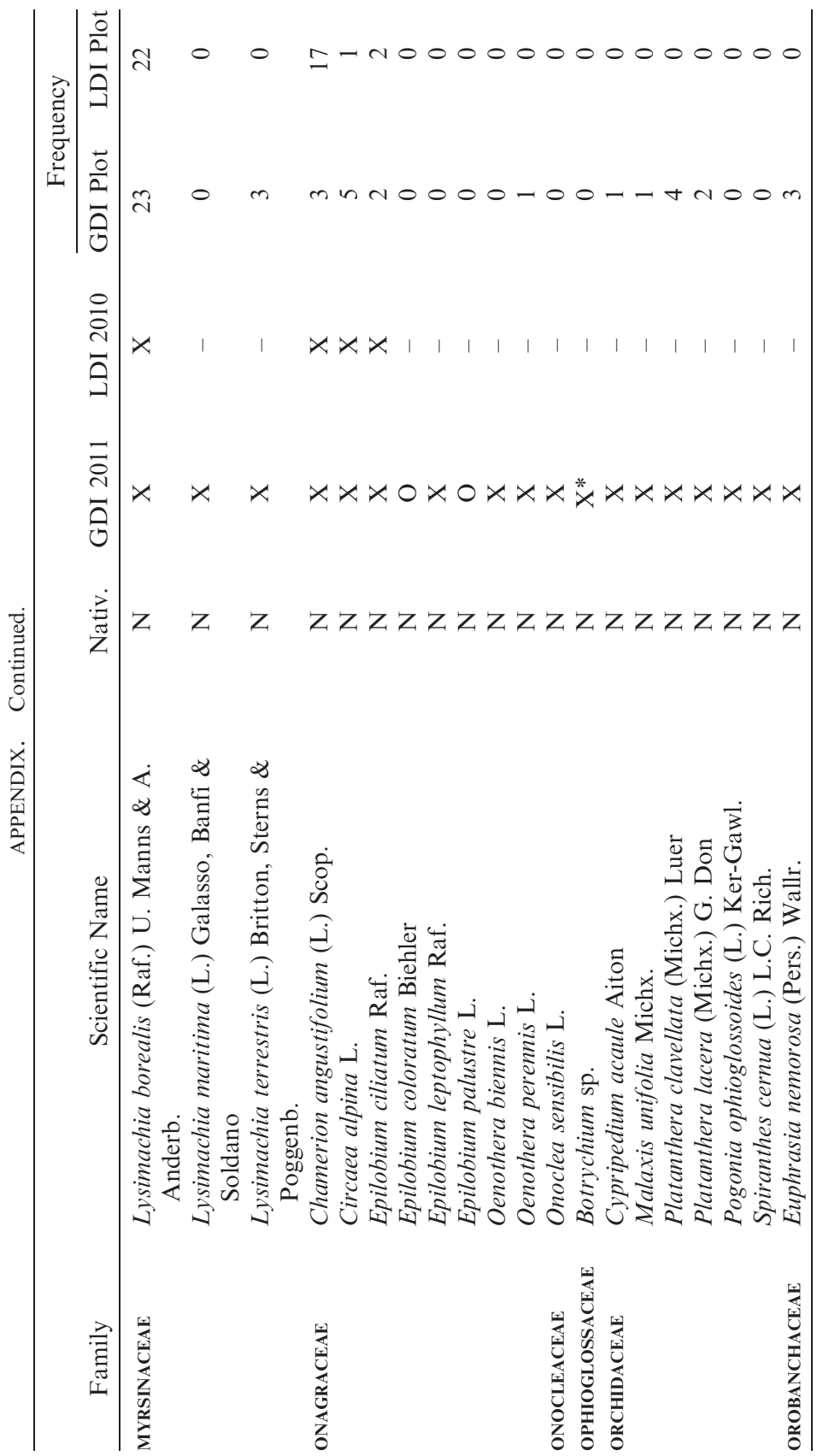




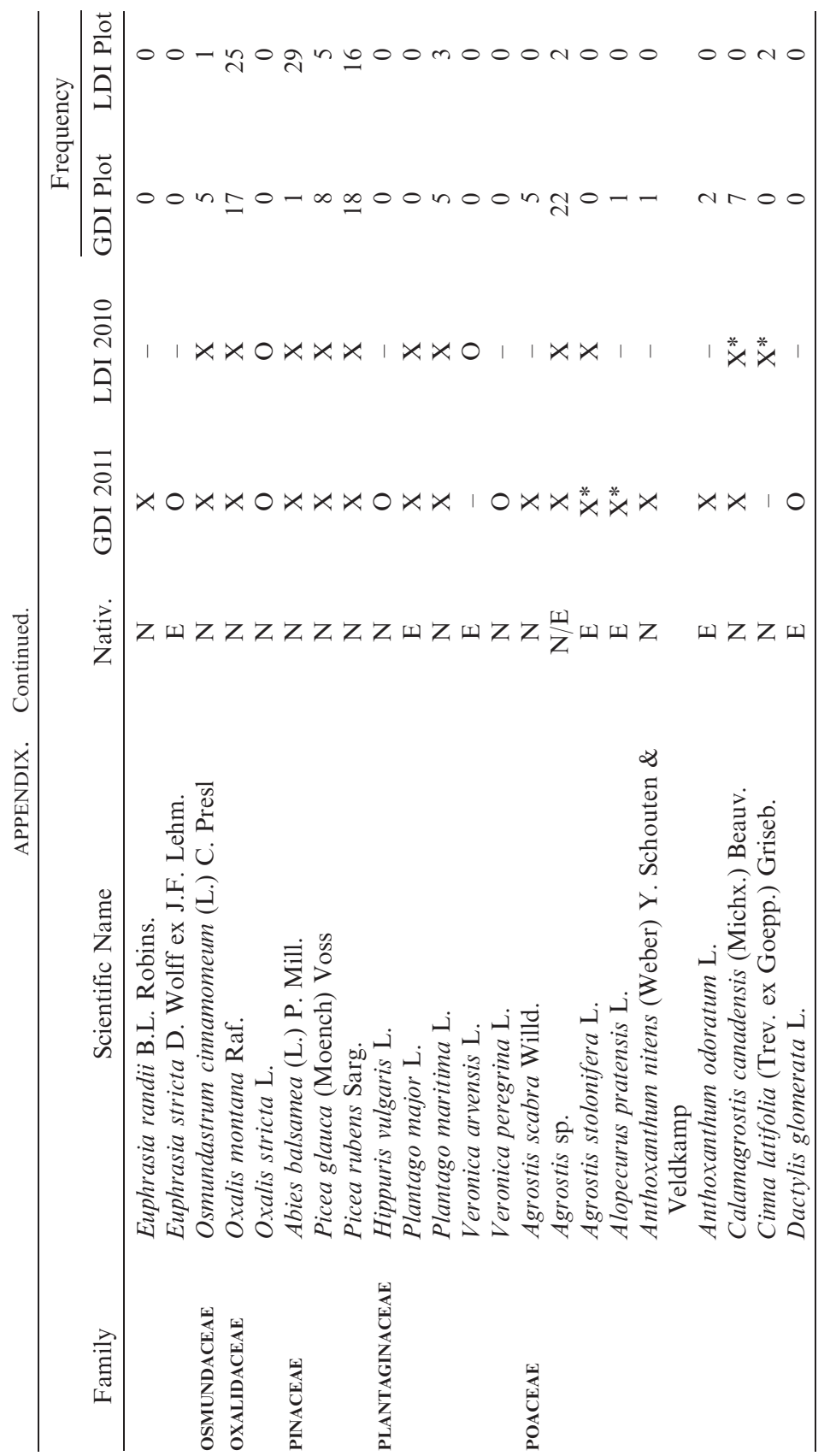




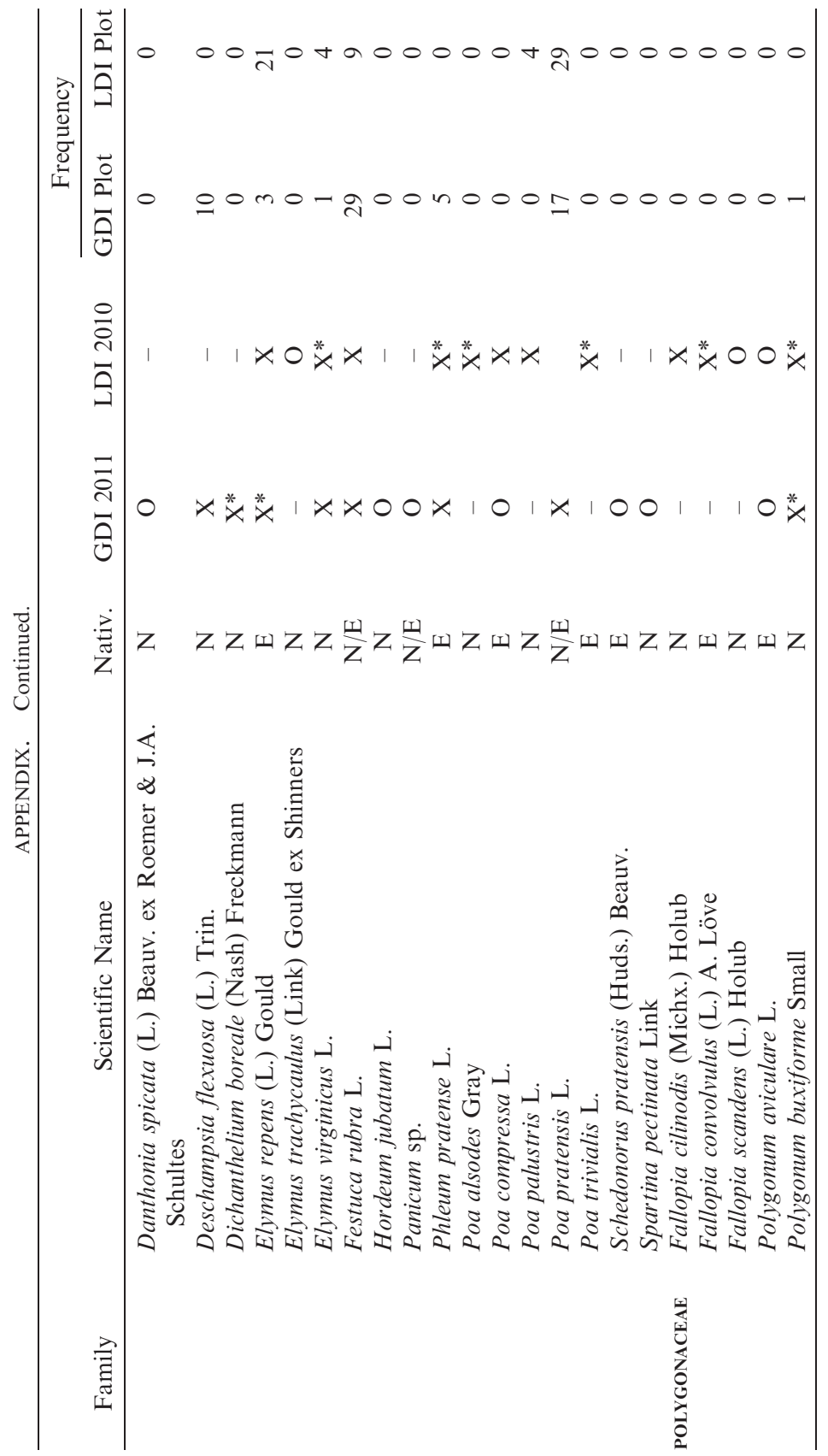




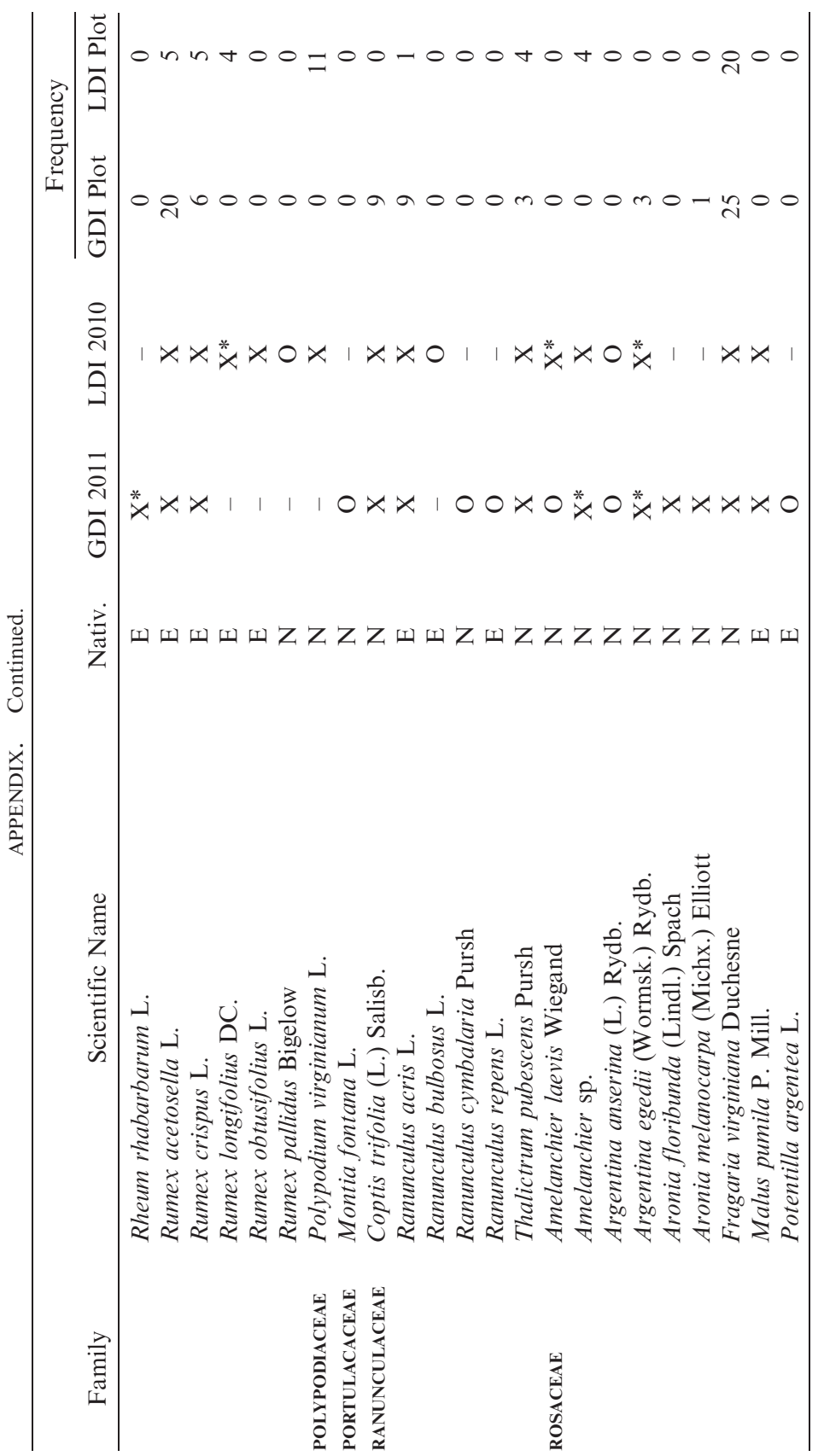




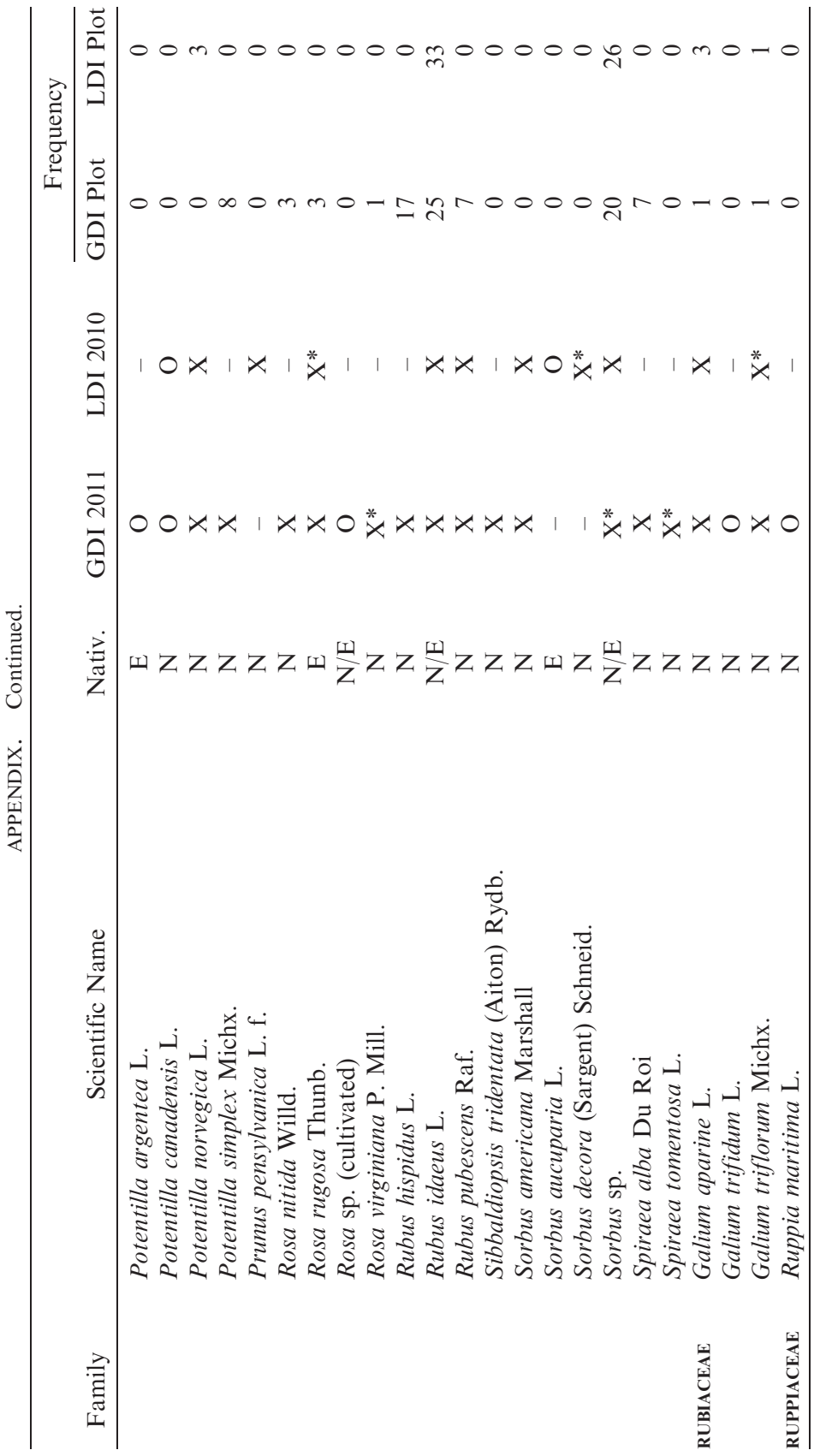




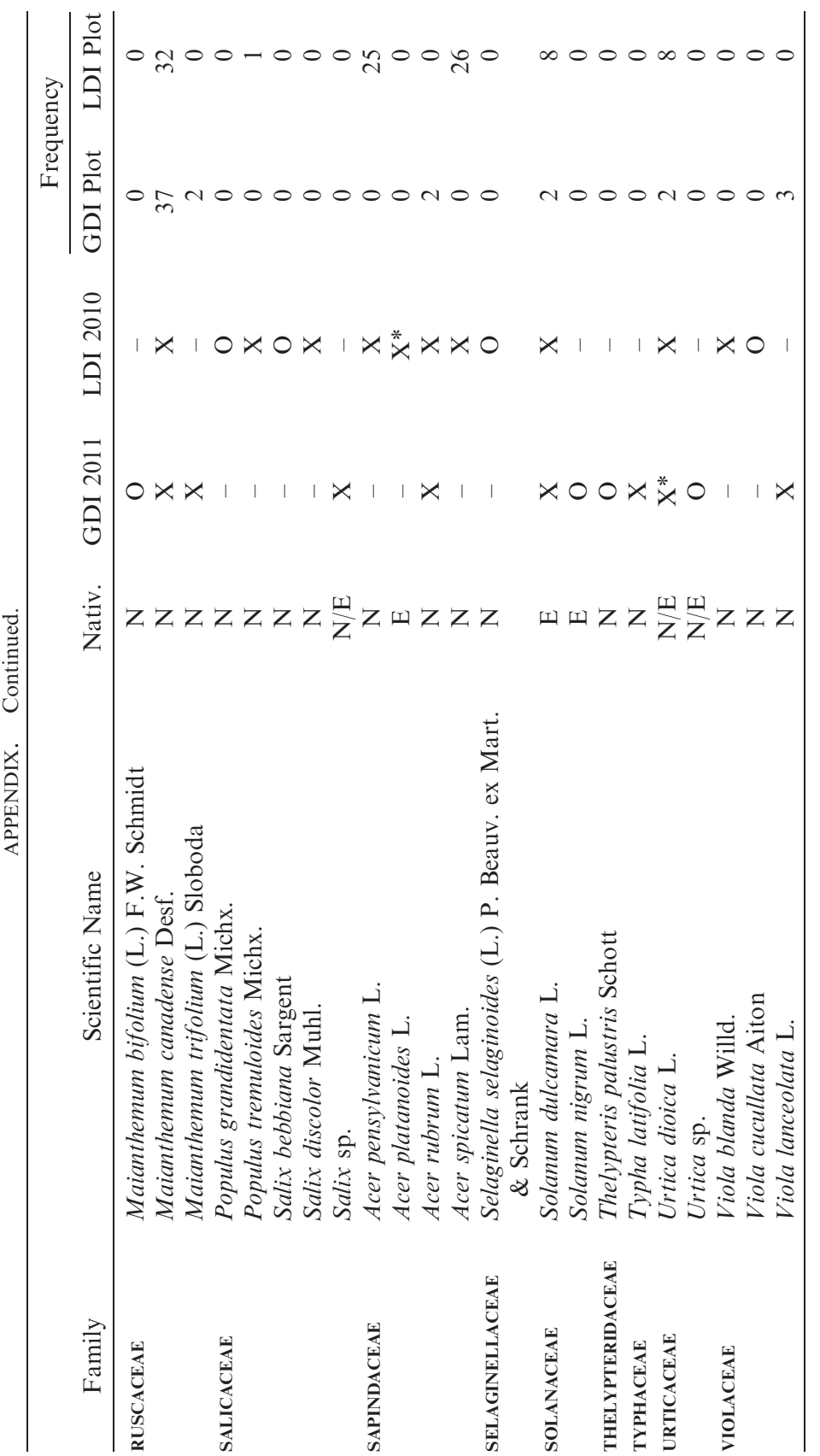




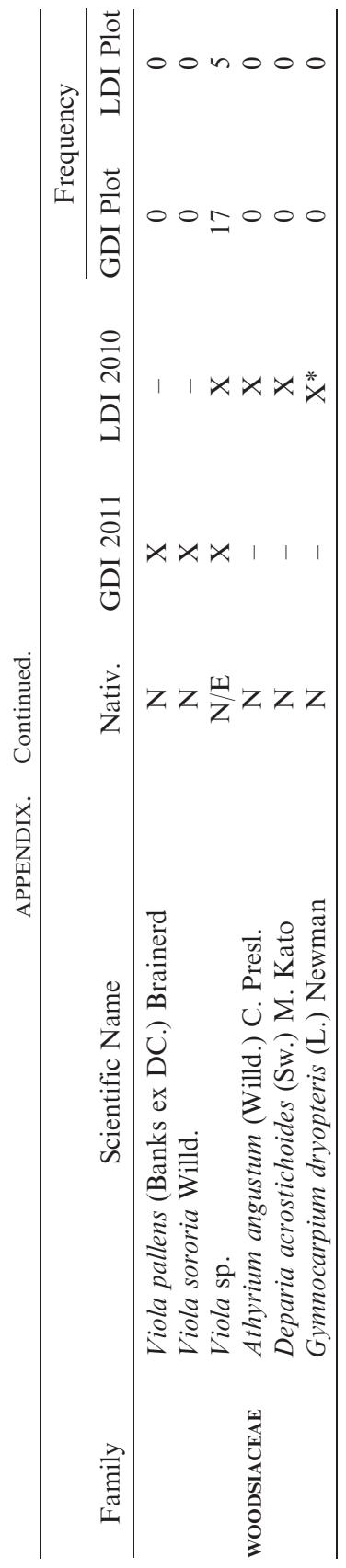

